Supplement of

\title{
Contribution of local and remote anthropogenic aerosols to a record-breaking torrential rainfall event in Guangdong Province, China
}

Zhen Liu et al.

Correspondence to: Steve Hung Lam Yim (steveyim@cuhk.edu.hk)

The copyright of individual parts of the supplement might differ from the CC BY 4.0 License. 


\section{S1. WRF-Chem model configuration}

WRF-Chem is a fully online model coupled with gas-phase chemistry mechanisms and aerosol physiochemical modules. In this model, chemical and meteorological components share the same grid coordinates, time steps, transport schemes, and subgrid physics. The meteorological component (WRF) of this coupled model uses an Eulerian dynamical core with a nonhydrostatic solver (Skamarock et al., 2008). Gas-phase chemical reactions are estimated using the carbon bond chemical mechanism (Zaveri and Peters, 1999). Aerosol physics and chemistry are treated using the Model for Simulating Aerosol Interactions and Chemistry (MOSAIC) scheme (Zaveri et al., 2008) with aqueous chemistry. The aerosol size distribution is represented by four discrete size bins within the MOSAIC scheme: 0.039-0.156 $\mu \mathrm{m}, 0.156-0.625 \mu \mathrm{m}, 0.625-2.5 \mu \mathrm{m}$, and 2.5$10 \mu \mathrm{m}$ (Fast et al., 2006). The approach to aerosol dry deposition is based on Binkowski and Shankar (1995). In-cloud (rainout) and below-cloud (washout) removal of aerosols by resolved clouds and precipitation are simulated following Easter et al. (2004) and Chapman et al. (2009), respectively. The transport and wet removal of aerosols by convective clouds are also considered using the Kain-Fritsch (KF) scheme (Kain and Fritsch, 1990) following Zhao et al. (2009, 2013). The major physical schemes of meteorological components comprise the KF cumulus scheme; the Yonsei University (YSU) planetary boundary layer (PBL) scheme (Hong et al., 2006); the National Center for Environmental Prediction, Oregon State University, Air Force, and Hydrologic Research Lab's (NOAH) land surface model (Chen and Dudhia, 2001); the Morrison two-moment scheme for cloud microphysics (Morrison et al., 2009); and the rapid radiative transfer for global (RRTMG) for both longwave and shortwave radiation schemes (Iacono et al., 2008). Aerosol interactions with shortwave and longwave radiation are incorporated into the model by linking aerosol optical properties, including optical depth, single-scattering albedo, and asymmetry factor, to RRTMG shortwave and longwave schemes, respectively (Zhao et al., 2010, 2011). The effects of ACI are estimated by considering the activation of aerosols to form cloud droplets based on the maximum supersaturation in the Morrison microphysical scheme (Chapman et al., 2009; Yang et al., 2011). 
S2. Figures

(a) Terrain Height

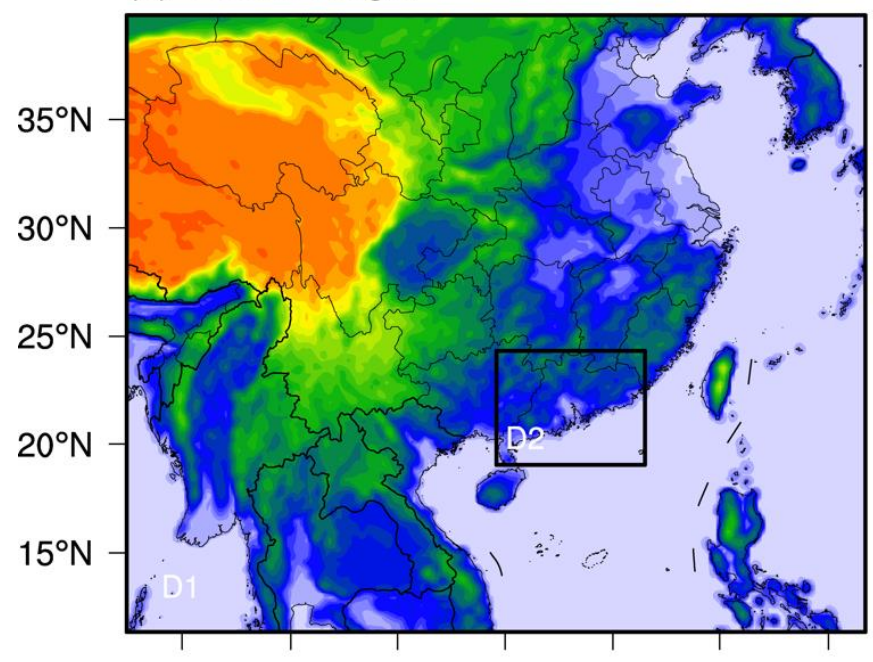

$95^{\circ} \mathrm{E} 100^{\circ} \mathrm{E} 105^{\circ} \mathrm{E} 110^{\circ} \mathrm{E} 115^{\circ} \mathrm{E} 120^{\circ} \mathrm{E} 125^{\circ} \mathrm{E}$ (b) Cloud Top Temperature

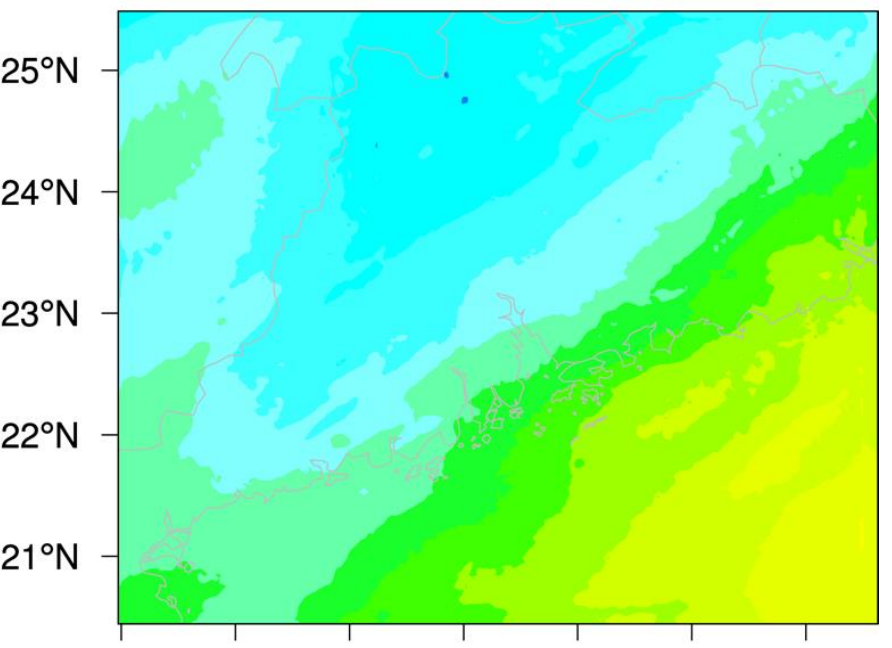

$110^{\circ} \mathrm{E} 111^{\circ} \mathrm{E} 112^{\circ} \mathrm{E} 113^{\circ} \mathrm{E} 114^{\circ} \mathrm{E} 115^{\circ} \mathrm{E} 116^{\circ} \mathrm{E}$
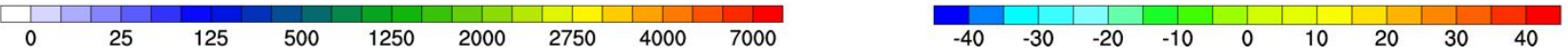

Figure S1. (a) WRF-Chem model two-nested domains with resolutions of $20 \mathrm{~km}$ and $4 \mathrm{~km}$ for domain 1 (D1) and domain 2 (D2), respectively. Shading represents terrain height $(\mathrm{m})$. (b) Spatial distribution of 3-day averaged cloud top temperature (shading; $\left.{ }^{\circ} \mathrm{C}\right)$ during December 14-16, 2013 over domain 2 in control run.

\section{0-hPa Z and Wind}
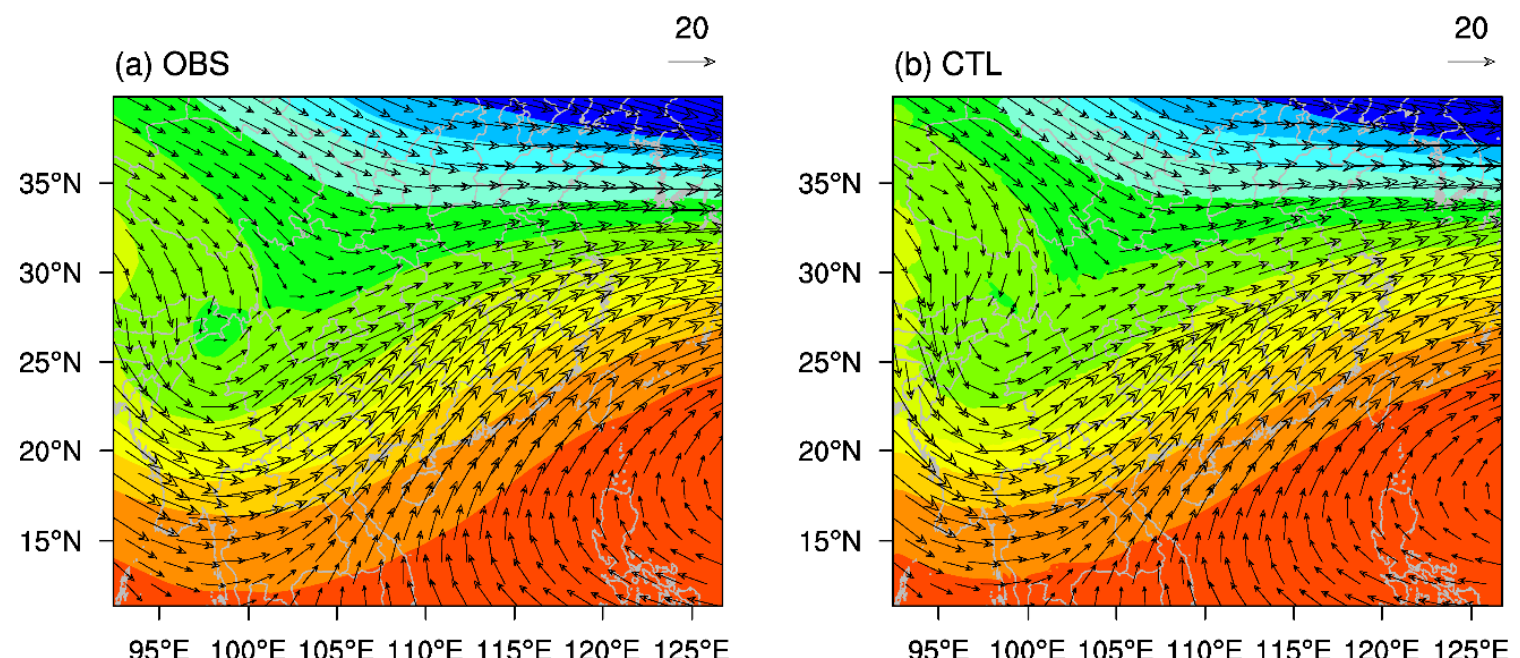

55005540558056205660570057405780582058605900 
Figure S2. Spatial distribution of 3-day averaged 500-hPa wind (vector; $\mathrm{m} \mathrm{s}^{-1}$ ) and height (shading; m) during December 14-16, 2013 for (a) OBS from ERA-interim and (b) CTL from control simulation.

\section{Surface Temperature $(\mathrm{K})$}

(a) 2013-12-14

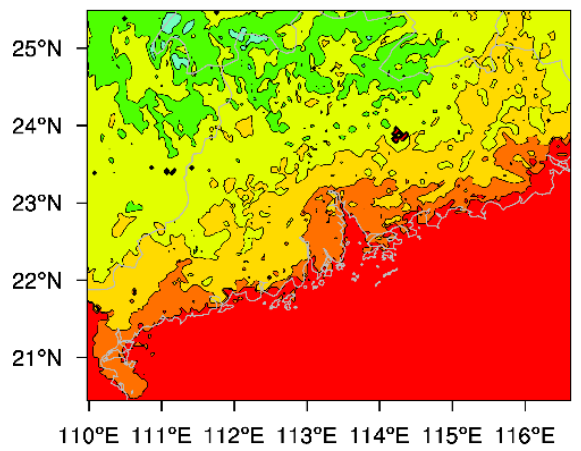

(b) 2013-12-15

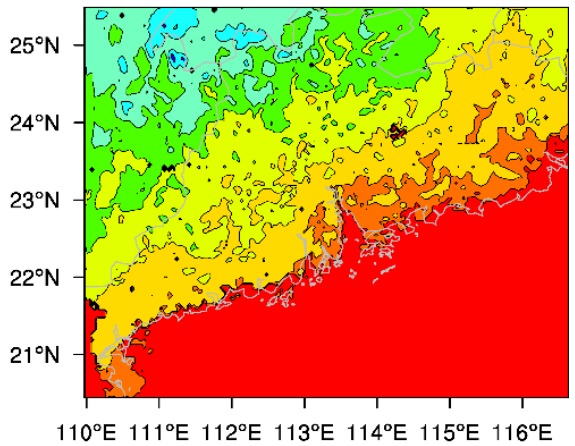

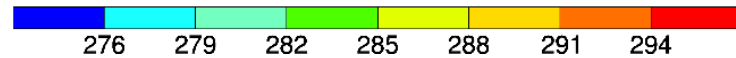

Figure S3. Spatial distribution of surface temperature (K) on (a) December 14 and (b) December 15 in 2013 in the CTL run.

$$
\mathrm{PM}_{2.5}
$$

(a) OBS

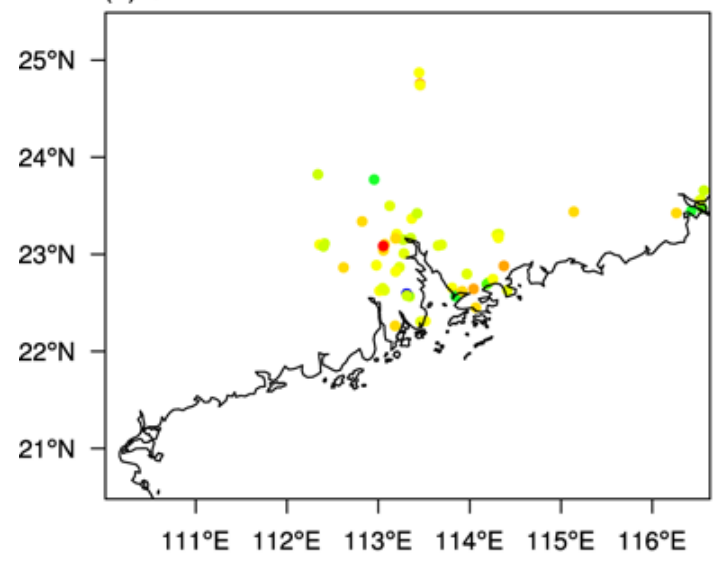

(b) CTL

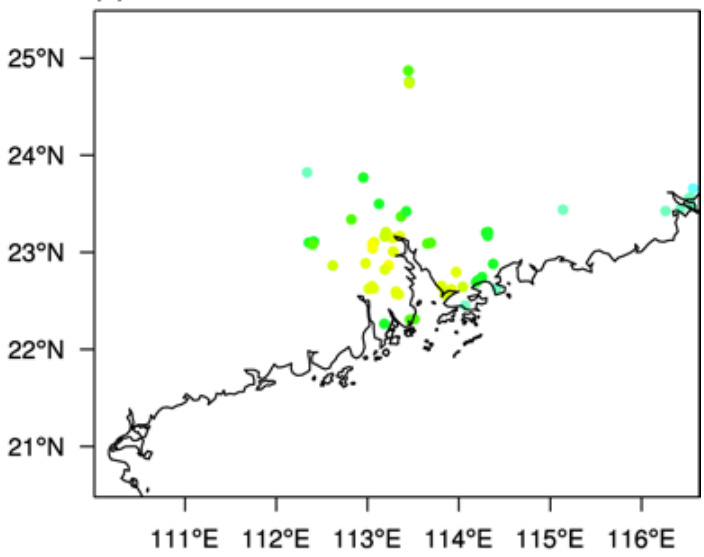

Figure S4. PM 2.5 concentration $\left(\mu \mathrm{g} \mathrm{m}^{-3}\right.$ ) average during December 14-16, 2013 for (a) observation and (b) control simulation. Colored circles denote in situ station locations. 


\section{$\mathrm{PM}_{2.5}$}

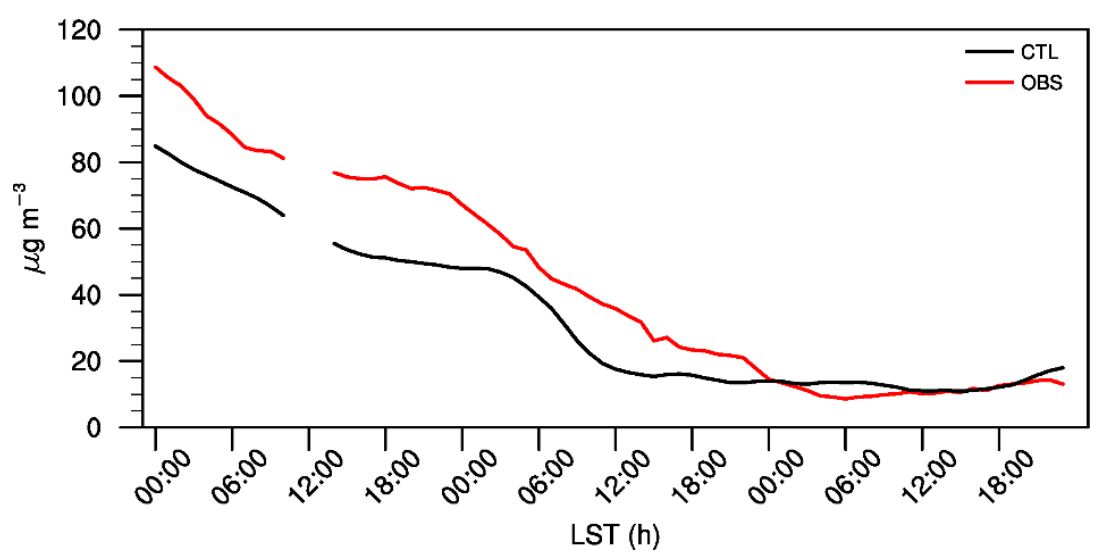

Figure S5. Time series of $\mathrm{PM}_{2.5}$ concentration averaged over all the air quality stations during December 14-16, 2013 for CTL (black) and OBS (red).

(a) OBS

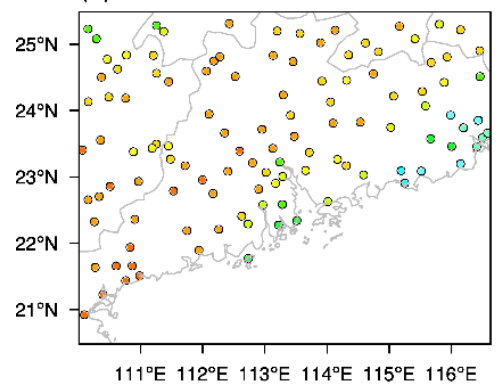

(c) CTL

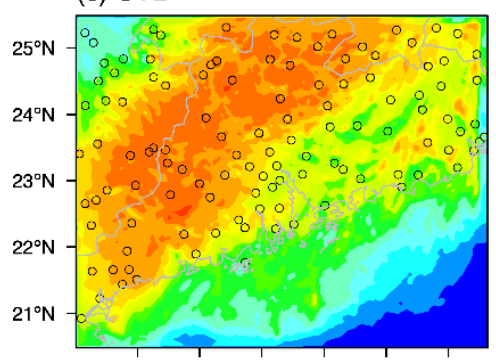

$111^{\circ} \mathrm{E} 112^{\circ} \mathrm{E} 113^{\circ} \mathrm{E} 114^{\circ} \mathrm{E} 115^{\circ} \mathrm{E} 116^{\circ} \mathrm{E}$ (b) CMORPH

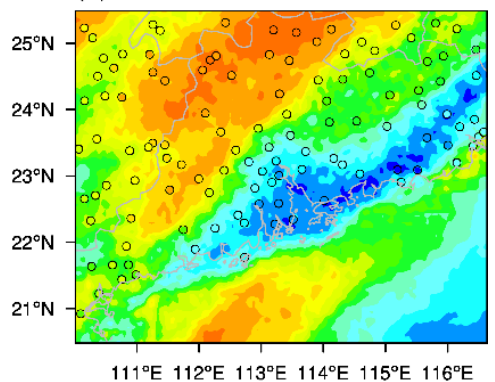

(d) TRMM

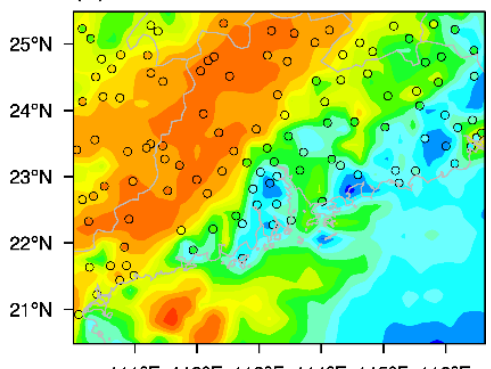

$111^{\circ} \mathrm{E} 112^{\circ} \mathrm{E} 113^{\circ} \mathrm{E} 114^{\circ} \mathrm{E} 115^{\circ} \mathrm{E} 116^{\circ} \mathrm{E}$

$\begin{array}{llllllllllllll}10 & 20 & 30 & 40 & 50 & 60 & 70 & 80 & 90 & 100 & 120 & 150 & 200 & 250\end{array}$

Figure S6. Spatial distribution of accumulated precipitation $(\mathrm{mm})$ from 00Z on December 14, 2013 to 00Z on December 17, 2013 from (a) station observations (OBS), (b) CMORPH, (c) control simulation (CTL), and (d) TRMM. Circles denote locations of in situ observations. 


\section{Precipitation}

(a) CTL-CLEAN

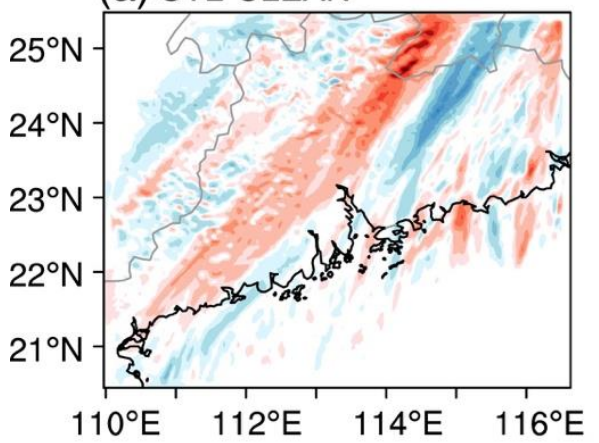

(b) CTL-ARIoff

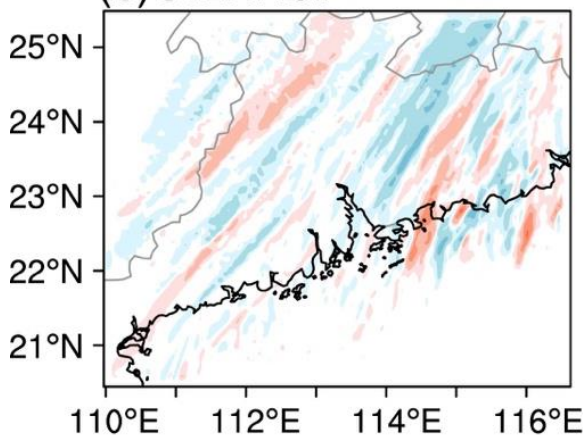

(c) ARloff-CLEAN

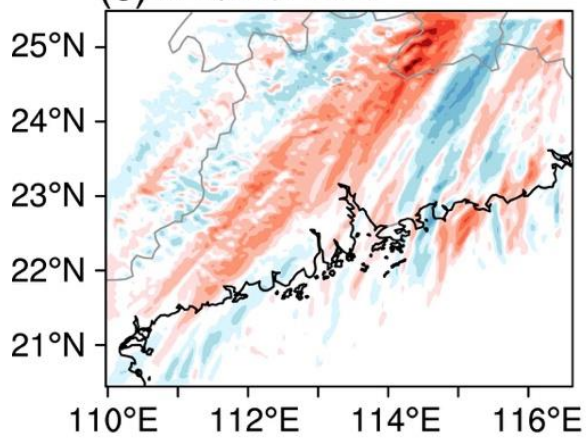

(d) D1-CLEAN

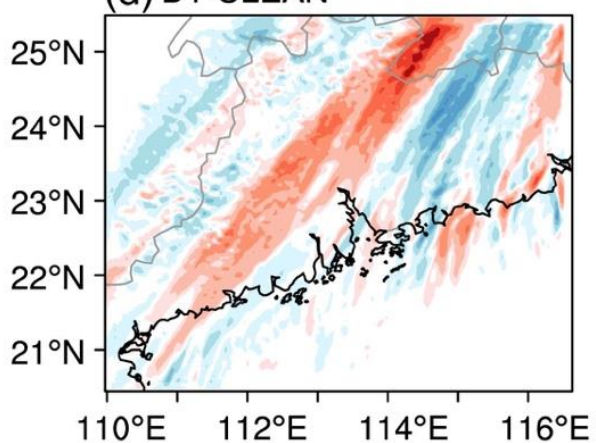

(e)D2-CLEAN

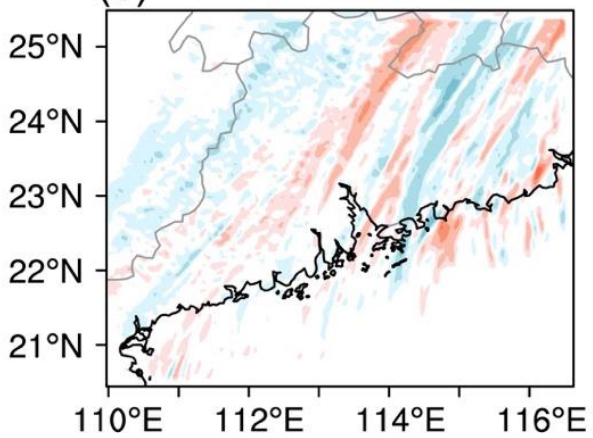

(f) 10X-CLEAN

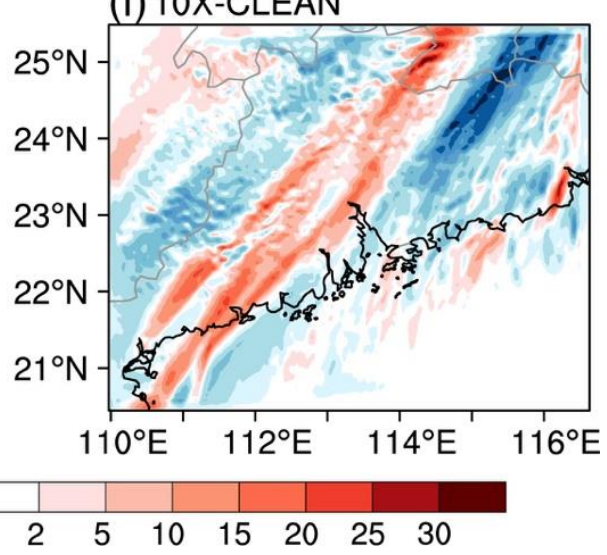

Figure S7. Differences in accumulated precipitation (mm) on December 16 between (a) CTL and CLEAN, (b) CTL and ARIoff, (c) ARIoff and CLEAN, (d) D1 and CLEAN, (e) D2 and CLEAN, and (f) 10x and CLEAN. ARIoff run refers to simulation with aerosolradiation interactions off. 


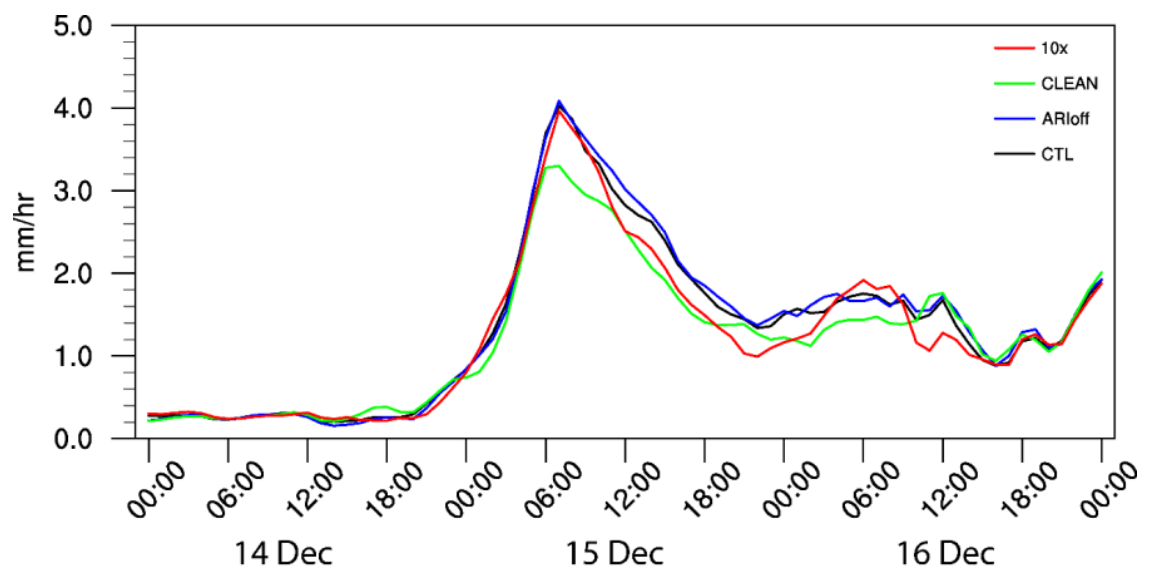

Figure S8. Time series of rain rate $\left(\mathrm{mm} \mathrm{h}^{-1}\right.$ ) averaged over R1 (a) for 10x (red), CTL (black), ARIoff (blue), and CLEAN (green).

Warm Cloud
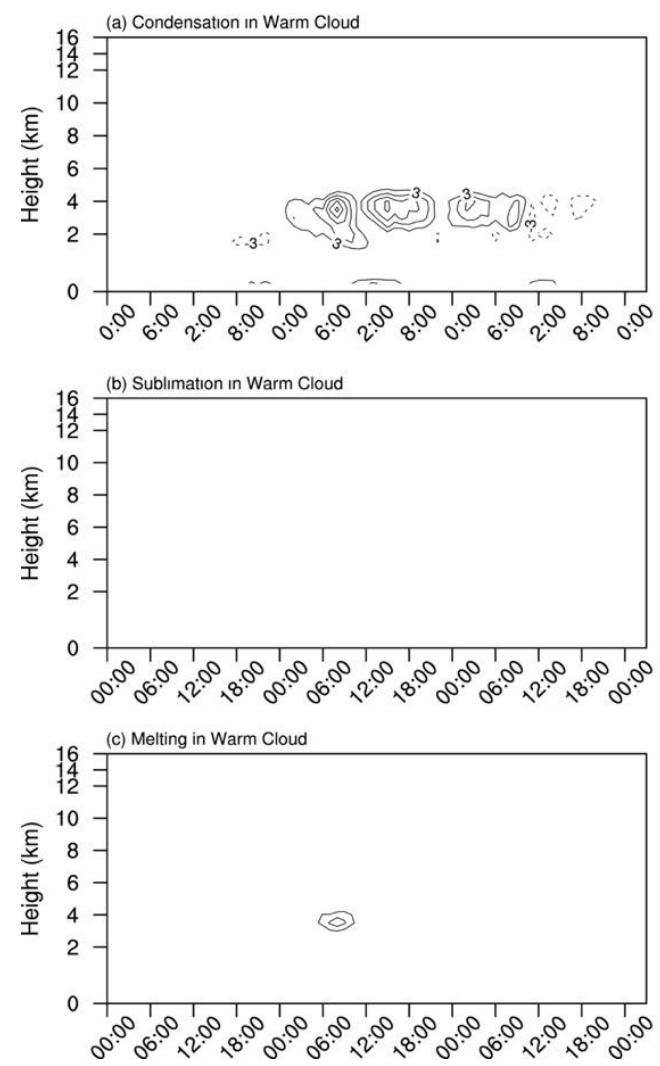

Cold Cloud
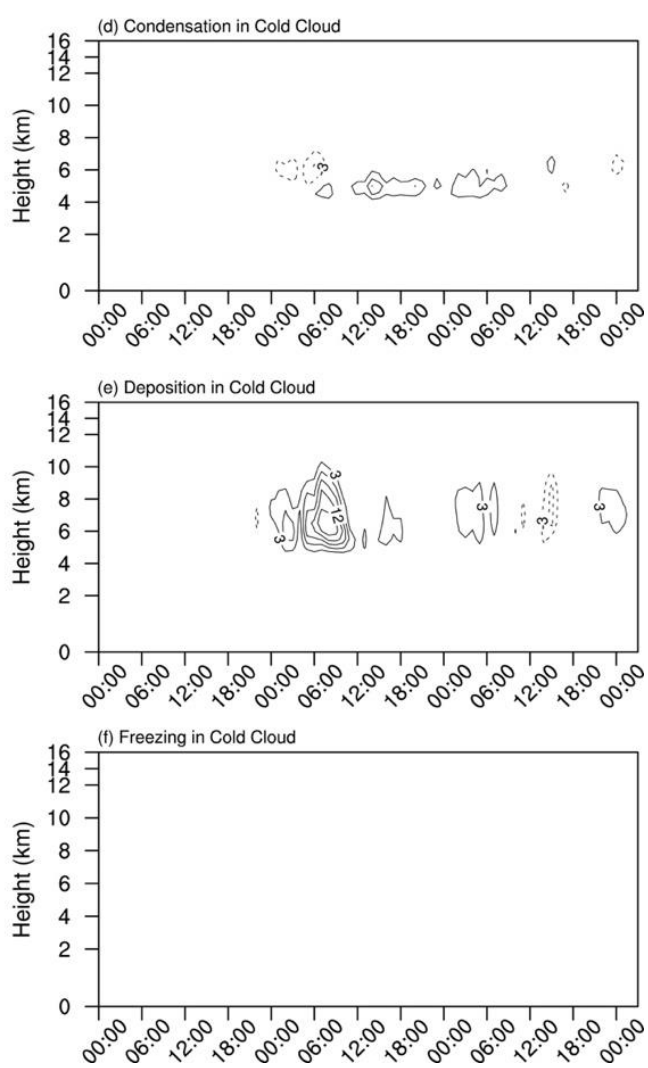

Figure S9. Differences with time (abscissa) and height (ordinate) in latent heat release ( $\mathrm{K} \mathrm{d}^{-1}$ ) from (a) condensation, (b) deposition, and (c) freezing processes between CTL and CLEAN averaged over R1 for warm cloud. (d-f) Same as (a-c) but for cold cloud. Zerovalue contour lines are omitted, and negative values are dashed. The contour interval is $3 \mathrm{~K} \mathrm{~d}^{-1}$. 

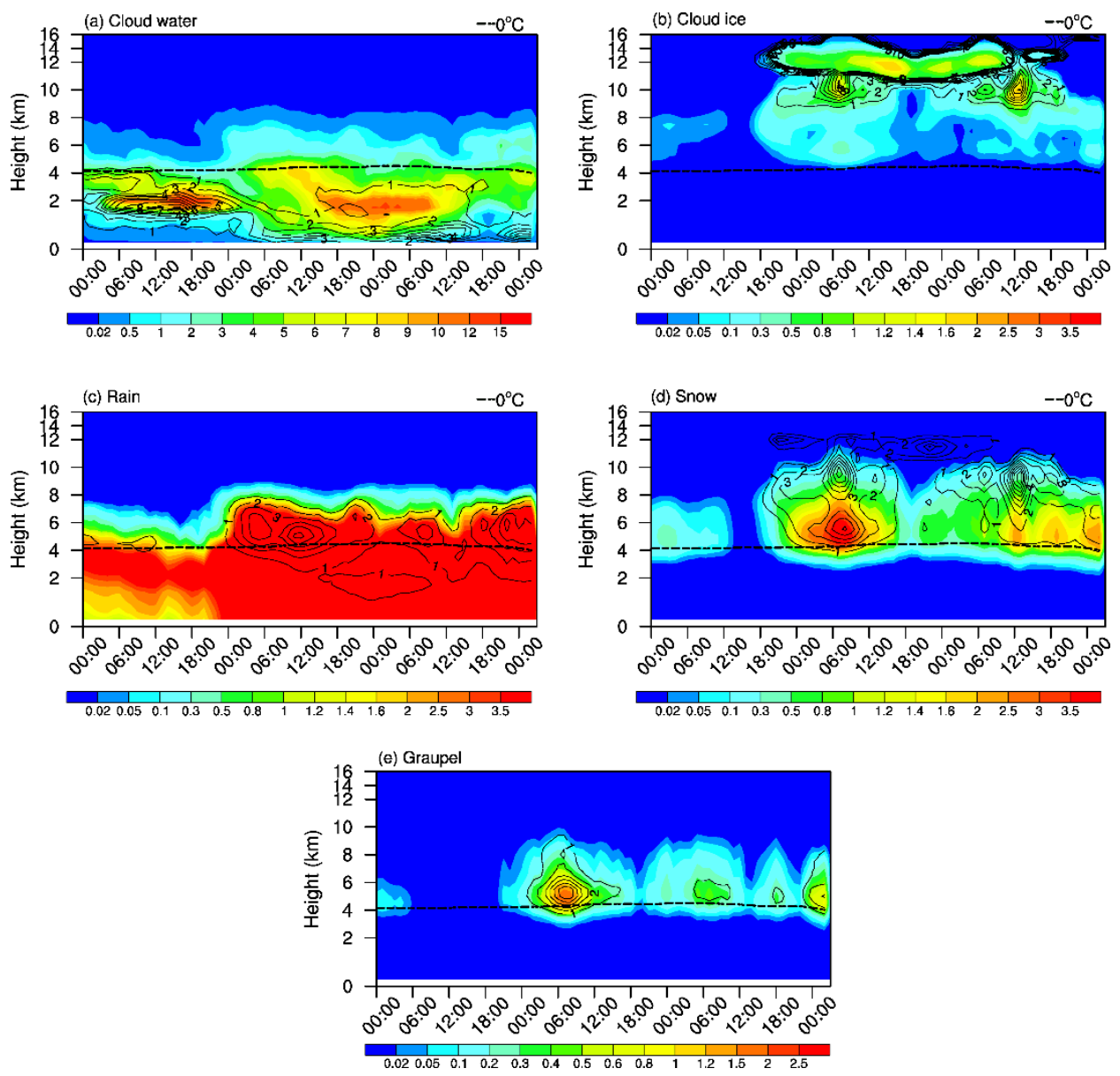

Figure S10. Distribution with time (abscissa) and height (ordinate) in (a) cloud water (shading; $1^{-5} \mathrm{~kg} \mathrm{~kg}^{-1}$ ) and CDNC (contour; $10^{7} \mathrm{~kg}^{-1}$ ), (b) cloud ice (shading; 10-5 kg kg-1) and CINC (contour; $10^{4} \mathrm{~kg}^{-1}$ ), (c) rain (shading; 10 ${ }^{-5} \mathrm{~kg} \mathrm{~kg}^{-1}$ ) and rain number concentration (contour; $10^{5} \mathrm{~kg}^{-1}$ ), (d) snow (shading; $10^{-4} \mathrm{~kg} \mathrm{~kg}^{-1}$ ) and snow number concentrations (contour; $10^{3} \mathrm{~kg}^{-1}$ ), and $(\mathrm{e}$ ) graupel (shading; $10^{-4} \mathrm{~kg} \mathrm{~kg}^{-1}$ ) and graupel number concentration (contour; $10^{3} \mathrm{~kg}^{-1}$ ) averaged over R1 in CTL run. 
Total

(a) $5.2 \mathrm{~mm}$

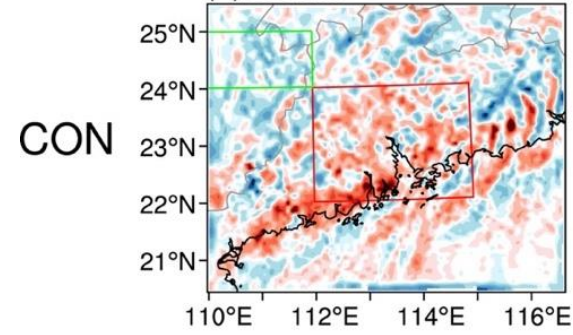

(c) $2.8 \mathrm{~mm}$

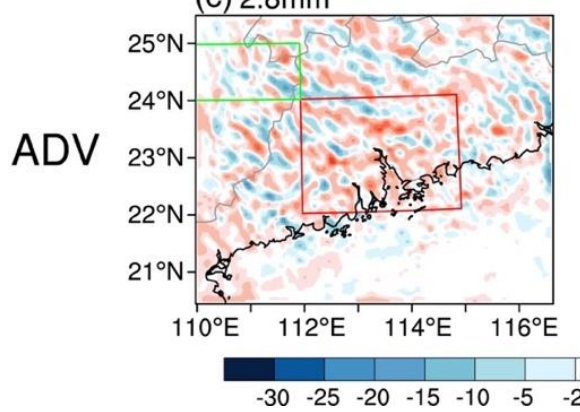

$\mathrm{ACl}$

(b) $7.1 \mathrm{~mm}$

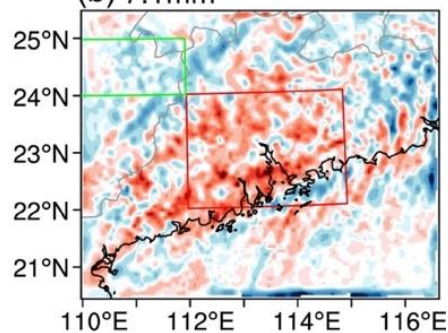

(d) $3.4 \mathrm{~mm}$

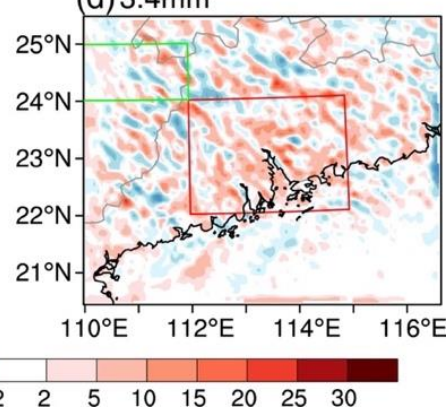

Figure S11. Differences in column-integrated moisture convergence (CON; mm) between (a) CTL and CLEAN and (b) ARIoff and CLEAN on December 15. (c, d) Same as (a, b) but for column-integrated advection of water vapor (ADV; mm). The numbers at the top-left corner of each panel represent the values averaged over $R 1$.
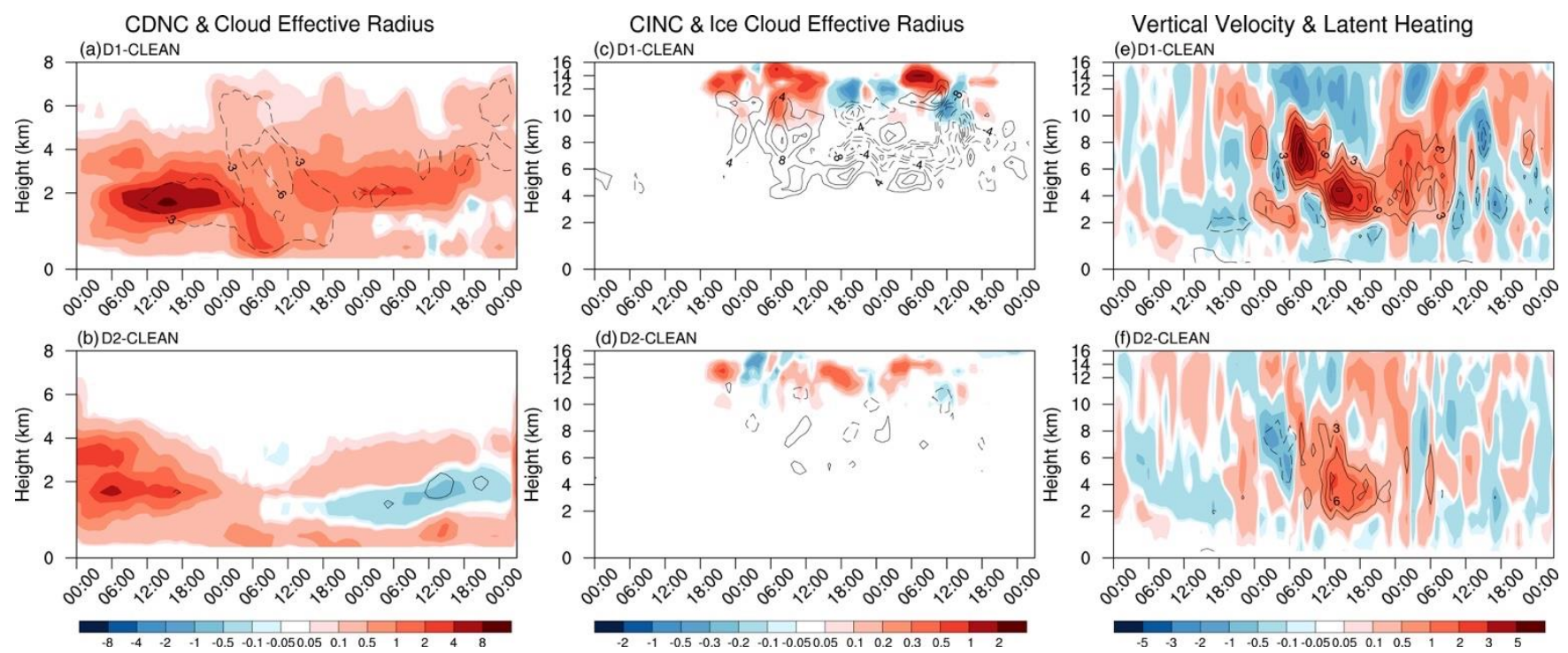

Figure S12. Differences with time (abscissa) and height (ordinate) in (a) CDNC (shading; $\mathbf{1 0}^{\mathbf{7}} \mathrm{kg}^{-1}$ ) and cloud effective radius (contour; $\mu \mathrm{m}$ ), (c) CINC (shading; $\mathbf{1 0}^{5} \mathrm{~kg}^{-1}$ ) and ice cloud effective radius (contour; $\mu \mathrm{m}$ ), and (e) vertical velocity (shading; cm $\mathrm{s}^{-1}$ ) and latent heating (contour; $\mathrm{K} \mathrm{d}^{-1}$ ) averaged over $\mathrm{R} 1$ between $\mathrm{D1}$ and CLEAN. (b, d, f) same as (a, c, e) but for differences between D2 and CLEAN. Zero-value contour lines are omitted, and negative values are dashed. 
Warm Cloud
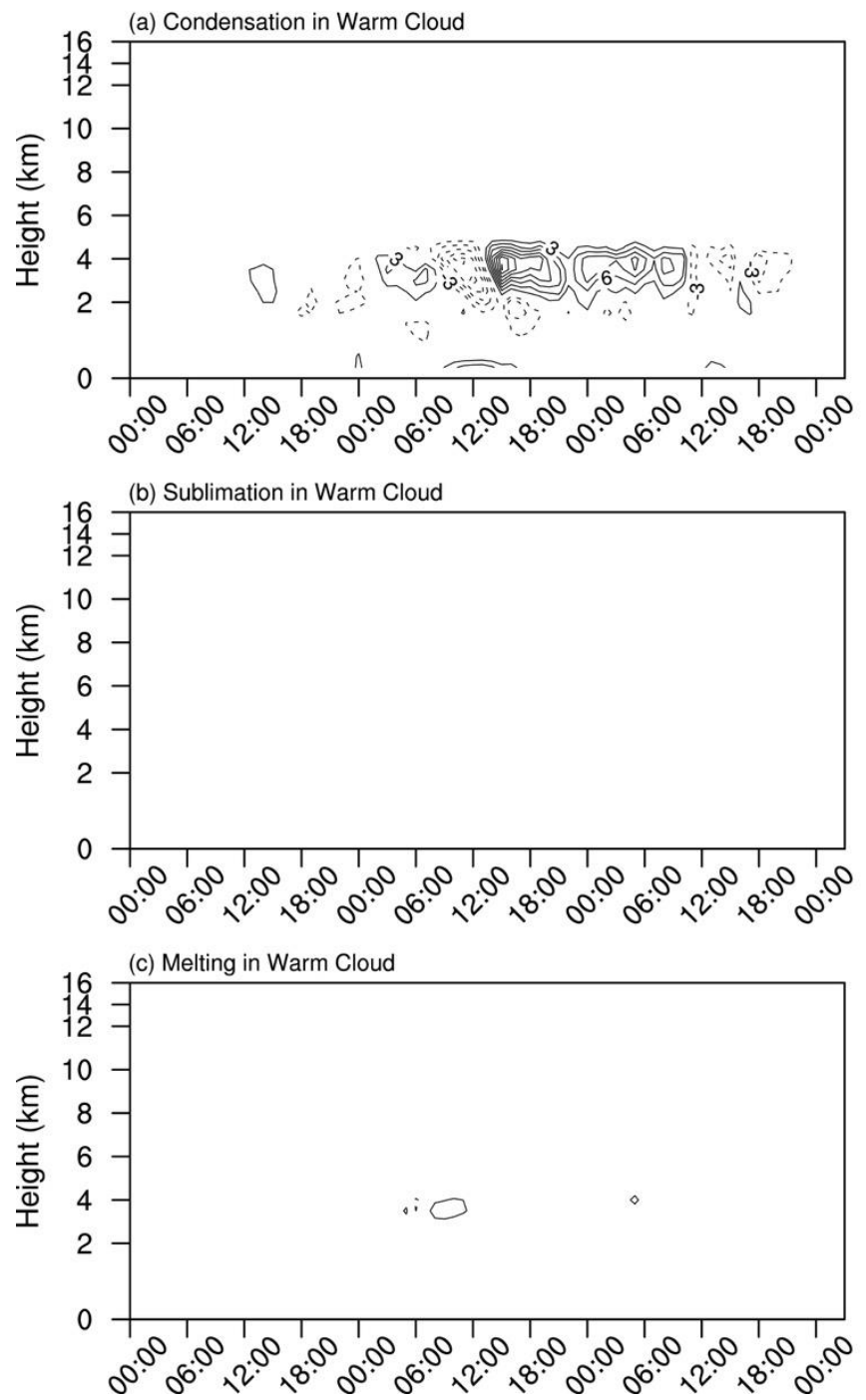

Cold Cloud
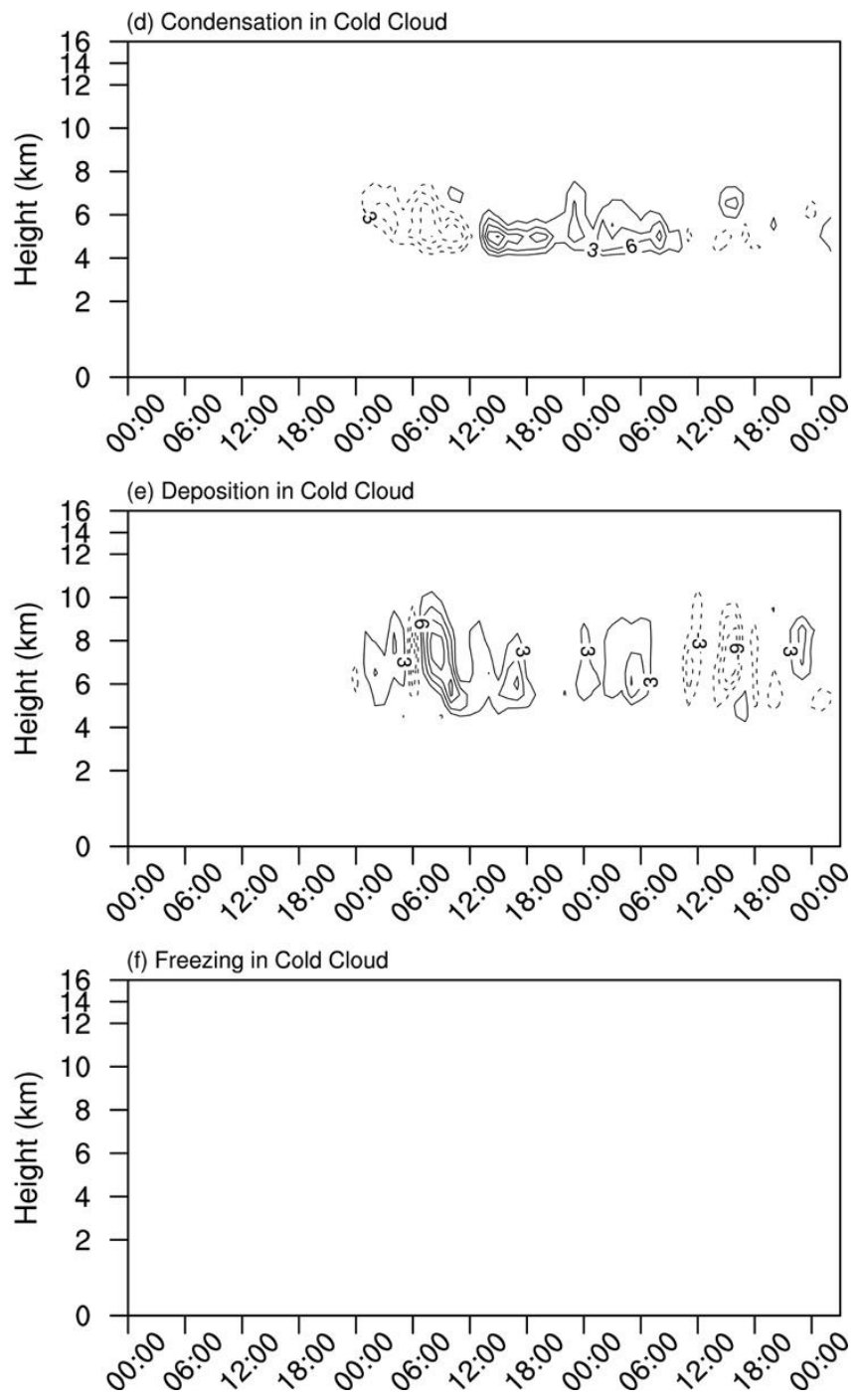

Figure S13. Differences with time (abscissa) and height (ordinate) in latent heat release $\left(\mathrm{K} \mathrm{d}^{-1}\right)$ from (a) condensation, (b) deposition, and (c) freezing processes between D1 and CLEAN averaged over R1 for warm cloud. (d-f) Same as (a-c) but for cold cloud. 

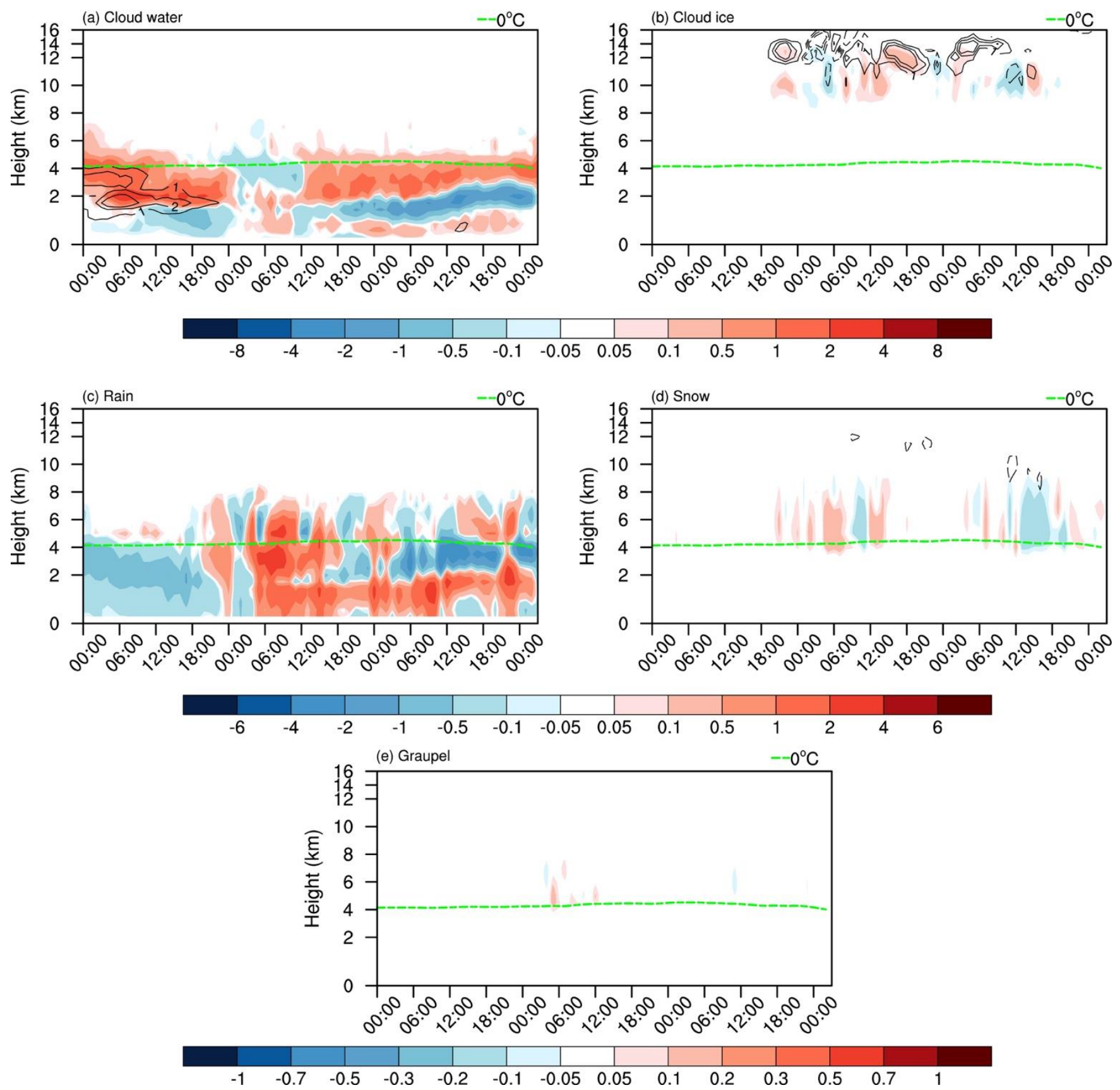

Figure S14. Differences with time (abscissa) and height (ordinate) in (a) cloud water (shading; $\mathbf{1 0}^{-5} \mathrm{~kg} \mathrm{~kg}^{-1}$ ) and CDNC (contour; $10^{7} \mathrm{~kg}^{-1}$ ), (b) cloud ice (shading; $10^{-5} \mathrm{~kg} \mathrm{~kg}^{-1}$ ) and CINC (contour; $10^{4} \mathrm{~kg}^{-1}$ ), (c) rain (shading; unit: $10^{-5} \mathrm{~kg} \mathrm{~kg}^{-1}$ ) and rain number concentration (contour; $10^{5} \mathrm{~kg}^{-1}$ ), (d) snow (shading; $10^{-4} \mathrm{~kg} \mathrm{~kg}^{-1}$ ) and snow number concentrations (contour; $\left.10^{3} \mathrm{~kg}^{-1}\right)$, and $(\mathrm{e})$ graupel (shading; $10^{-4} \mathrm{~kg} \mathrm{~kg}^{-1}$ ) and graupel number concentration (contour; $10^{3} \mathrm{~kg}^{-1}$ ) between D2 and CLEAN averaged over R1. 
Warm Cloud
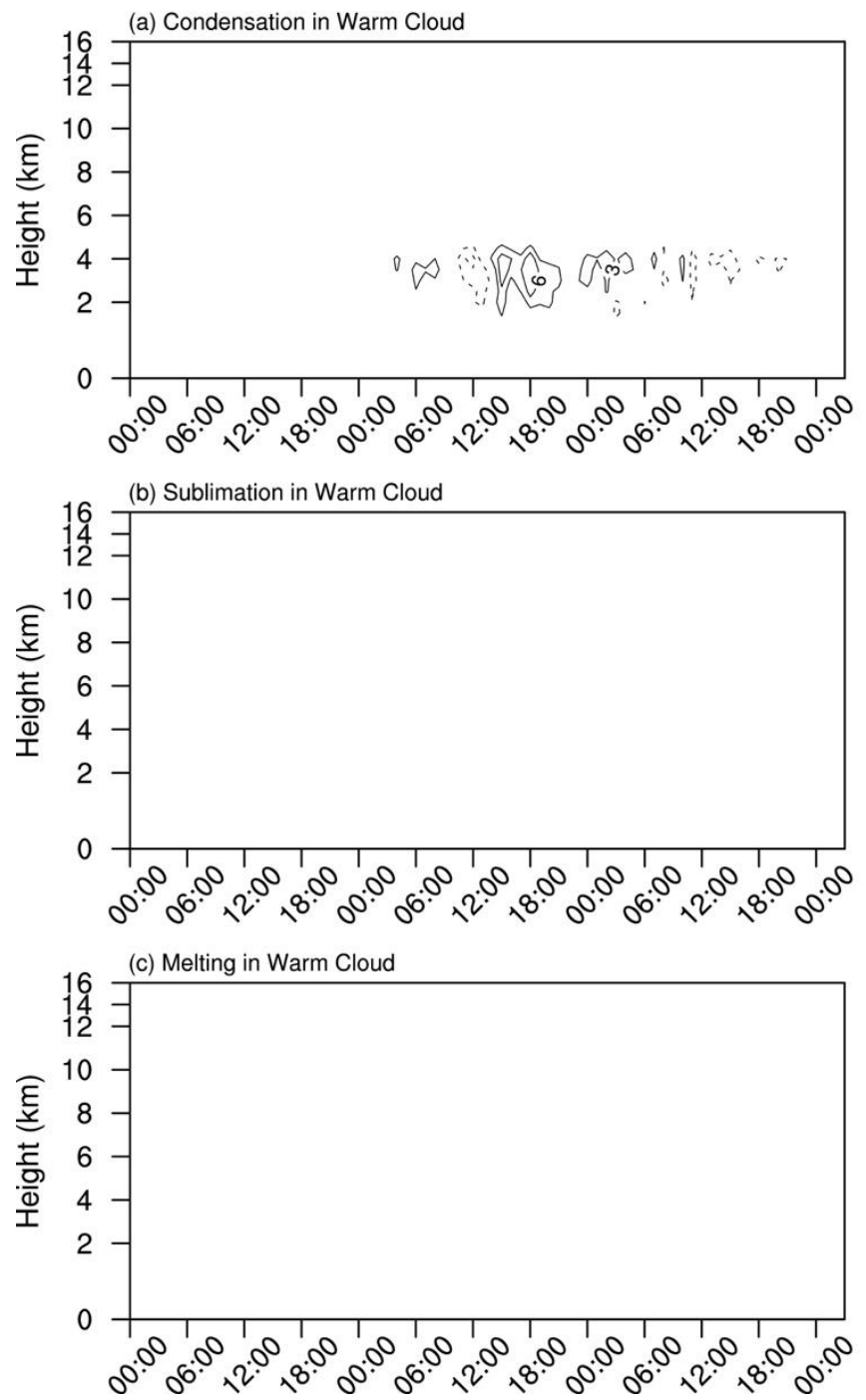

Cold Cloud
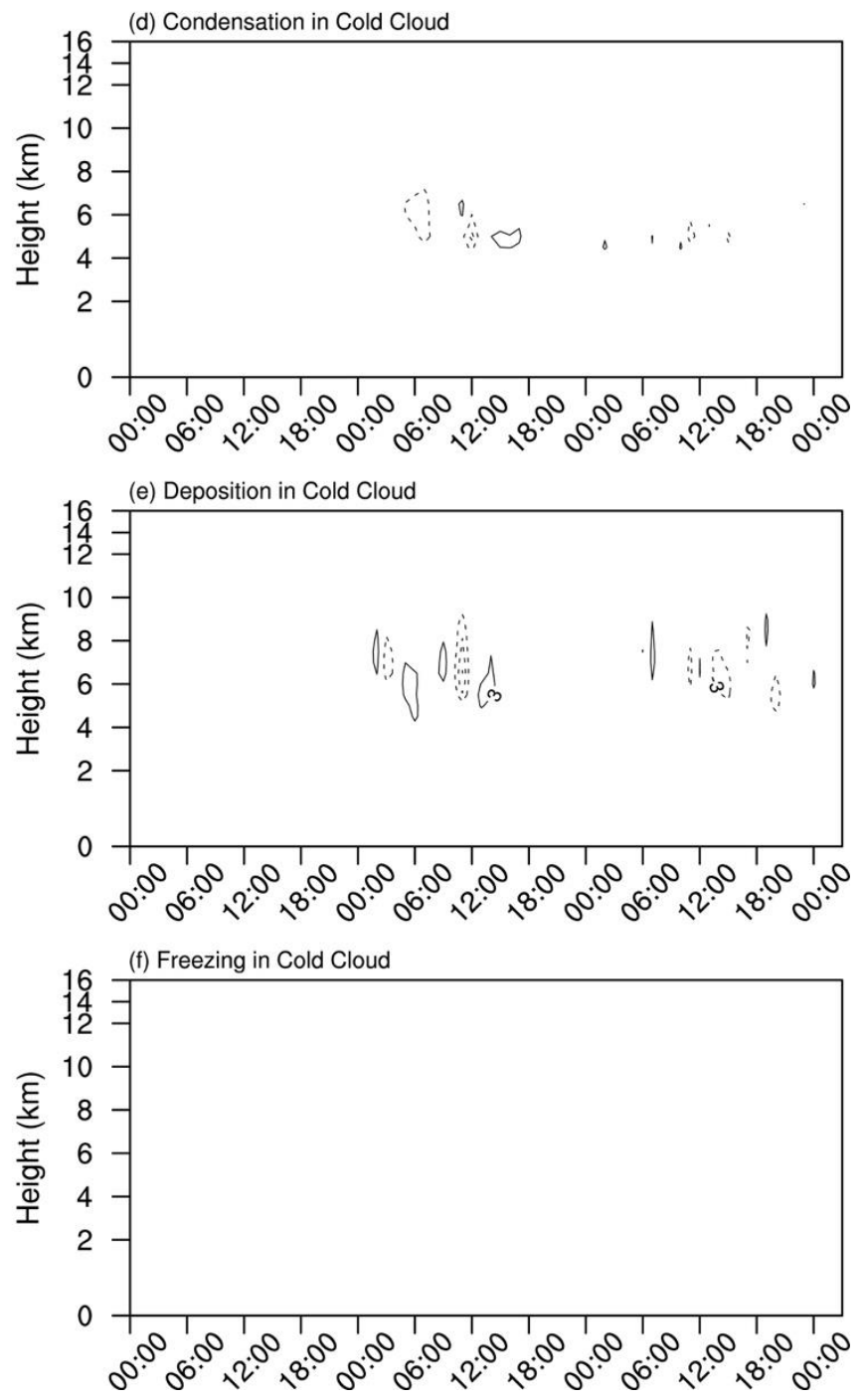

Figure S15. Differences with time (abscissa) and height (ordinate) in latent heat release ( $\left.\mathrm{K} \mathrm{d}^{-1}\right)$ from (a) condensation, (b) deposition, and (c) freezing processes between D2 and CLEAN averaged over R1 for warm cloud. (d-f) Same as (a-c) but for cold cloud. Zerovalue contour lines are omitted, and negative values are dashed. The contour interval is $3 \mathrm{~K} \mathrm{~d}^{-1}$. 


\section{$\mathrm{CF} \& \mathrm{PM}_{2.5}$}

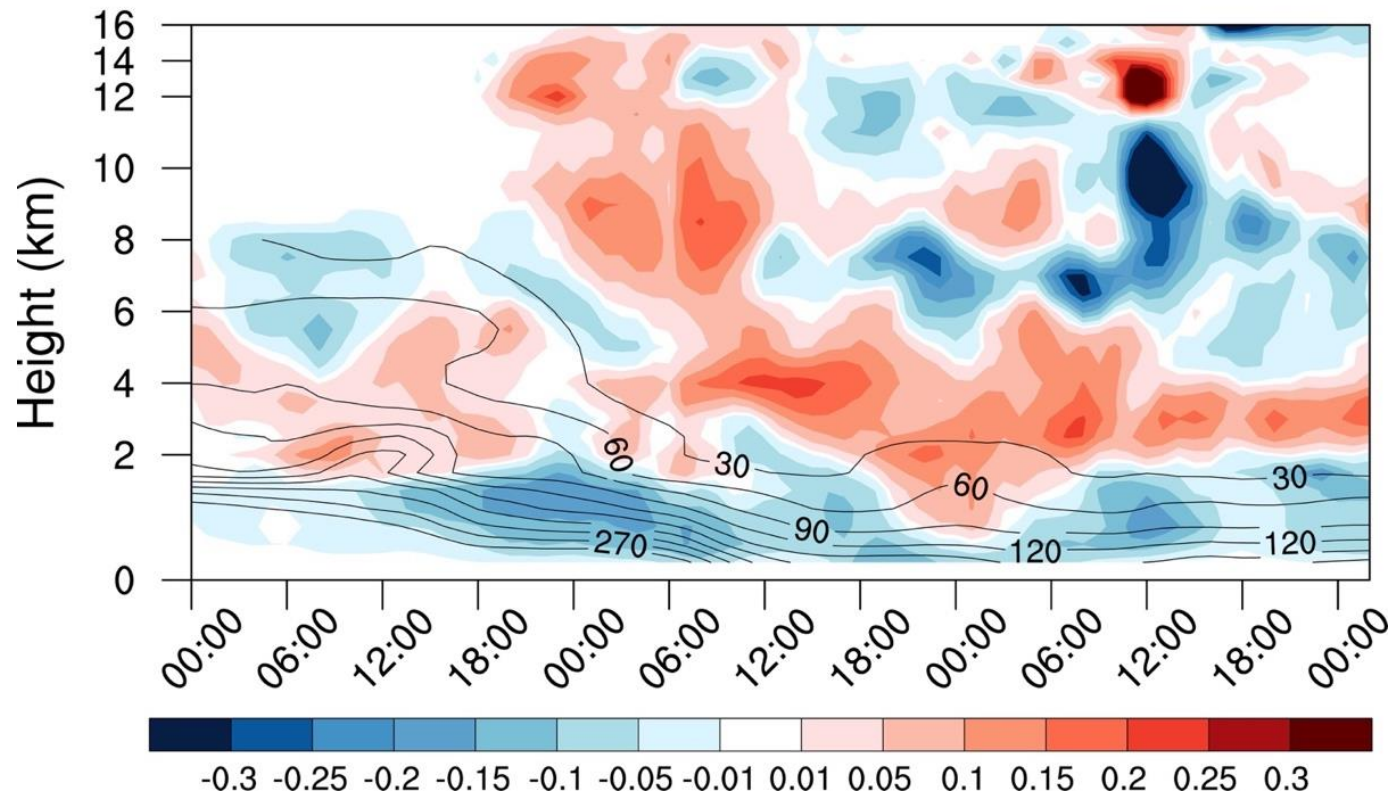

Figure S16. Differences in the time-height cross section of cloud factor CF (shading; unitless) and PM2.5 concentration (contour; $\mu \mathrm{g}$ $\mathrm{m}^{-3}$ ) averaged over $\mathrm{R} 1$ between $10 \times$ and CLEAN. 
(a) CDNC \& Cloud Effective Radius

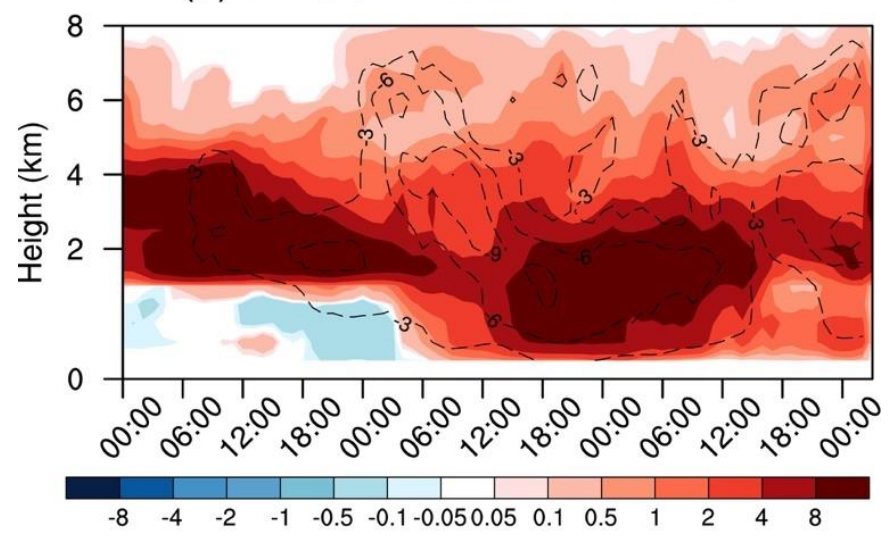

(b) CINC \& Ice Cloud Effective Radius

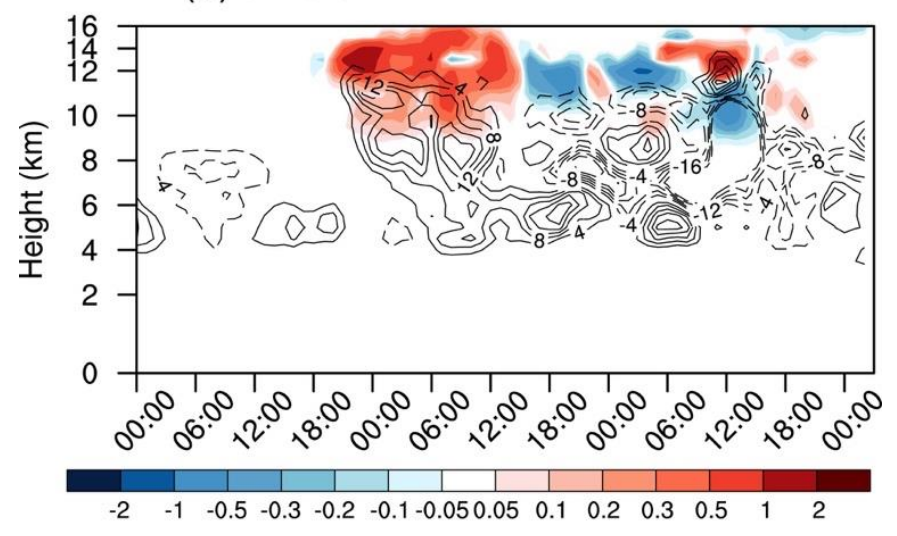

(c) Vertical Velocity \& Latent Heating

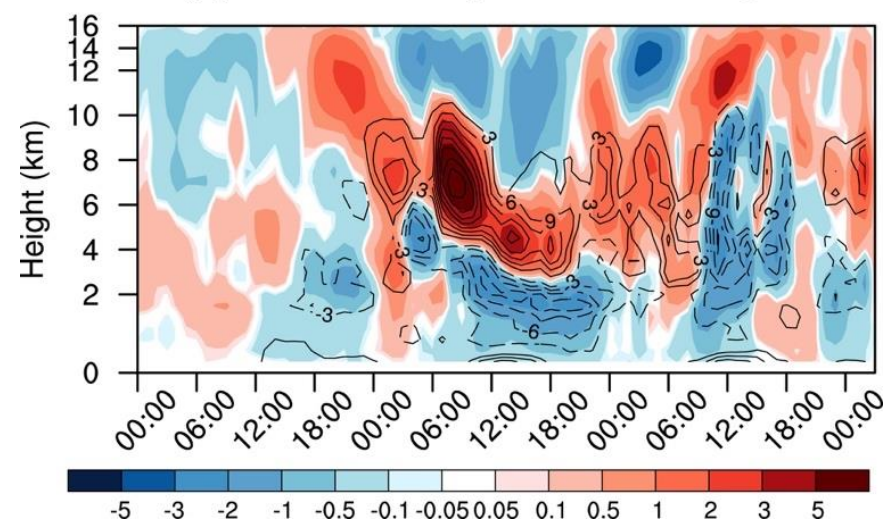

Figure S17. Differences with time (abscissa; from $00 \mathrm{Z}$ on December 14 to $02 \mathrm{Z}$ on December 17) and height (ordinate) in (a) CDNC (shading; $10^{7} \mathrm{~kg}^{-1}$ ) and cloud effective radius $(\mu \mathrm{m}),(\mathrm{b}) \mathrm{CINC}$ (shading; $10^{5} \mathrm{~kg}^{-1}$ ) and ice cloud effective radius (contour; $\mu \mathrm{m}$ ), and (c) vertical velocity (shading; $\mathrm{cm} \mathrm{s}^{-1}$ ) and latent heating (contour; $\mathrm{K} \mathrm{d}^{-1}$ ) averaged over $\mathrm{R} 1$ between $10 \times$ and CLEAN. 

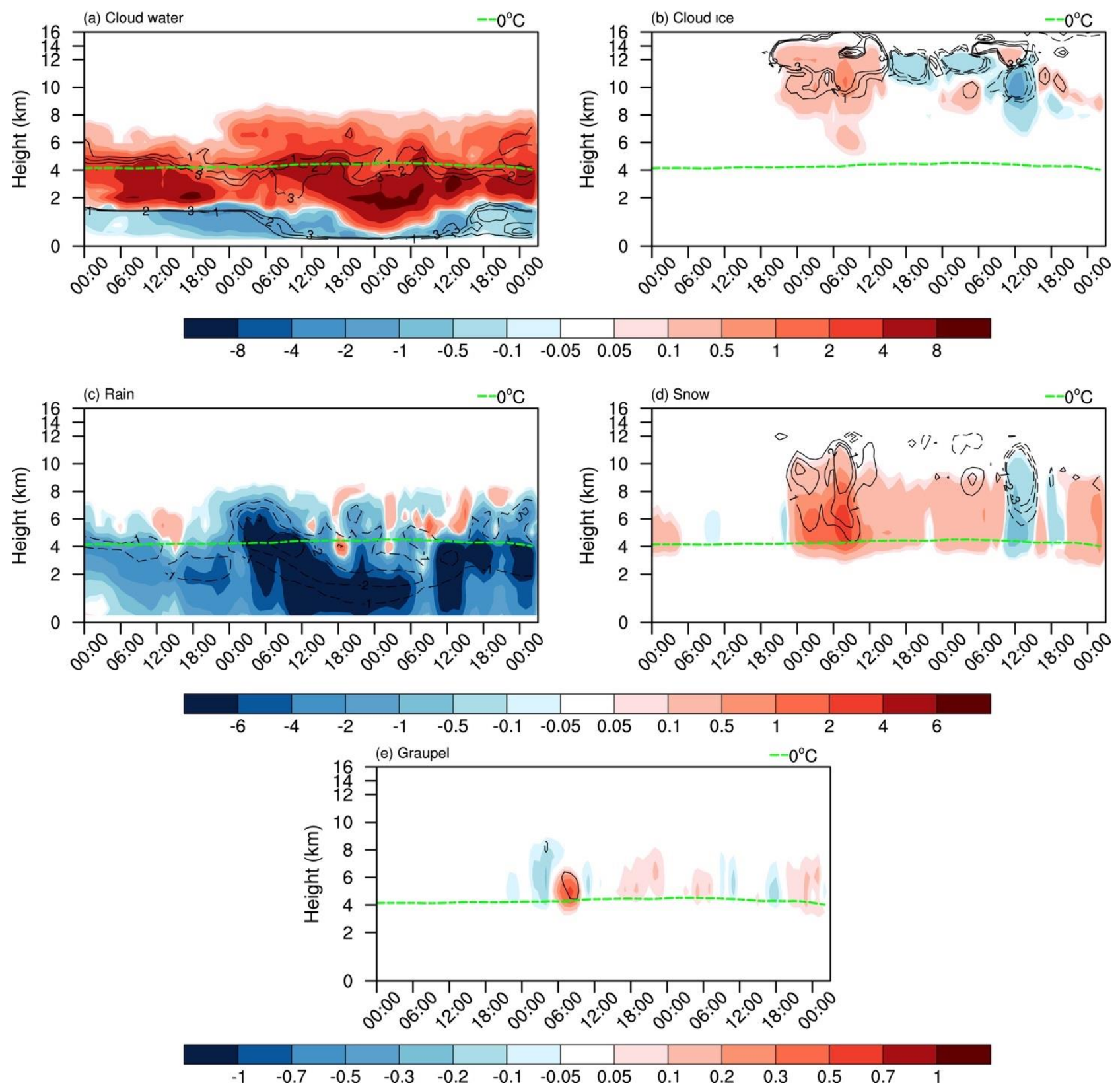

Figure S18. Differences with time (abscissa) and height (ordinate) in (a) cloud water (shading; $\mathbf{1 0}^{-5} \mathrm{~kg} \mathrm{~kg}^{-1}$ ) and CDNC (contour; $10^{7} \mathrm{~kg}^{-1}$ ), (b) cloud ice (shading; $10^{-5} \mathrm{~kg} \mathrm{~kg}^{-1}$ ) and CINC (contour; $10^{4} \mathrm{~kg}^{-1}$ ), (c) rain (shading; $1^{-5} \mathrm{~kg} \mathrm{~kg}^{-1}$ ) and rain number concentration (contour; $10^{5} \mathrm{~kg}^{-1}$ ), (d) snow (shading; $10^{-4} \mathrm{~kg} \mathrm{~kg}^{-1}$ ) and snow number concentration (contour; $10^{3} \mathrm{~kg}^{-1}$ ), and (e) graupel (shading; $10^{-4} \mathrm{~kg} \mathrm{~kg}^{-1}$ ) and graupel number concentration (contour; $10^{3} \mathrm{~kg}^{-1}$ ) between 10× and CLEAN averaged over R1. 
Warm Cloud
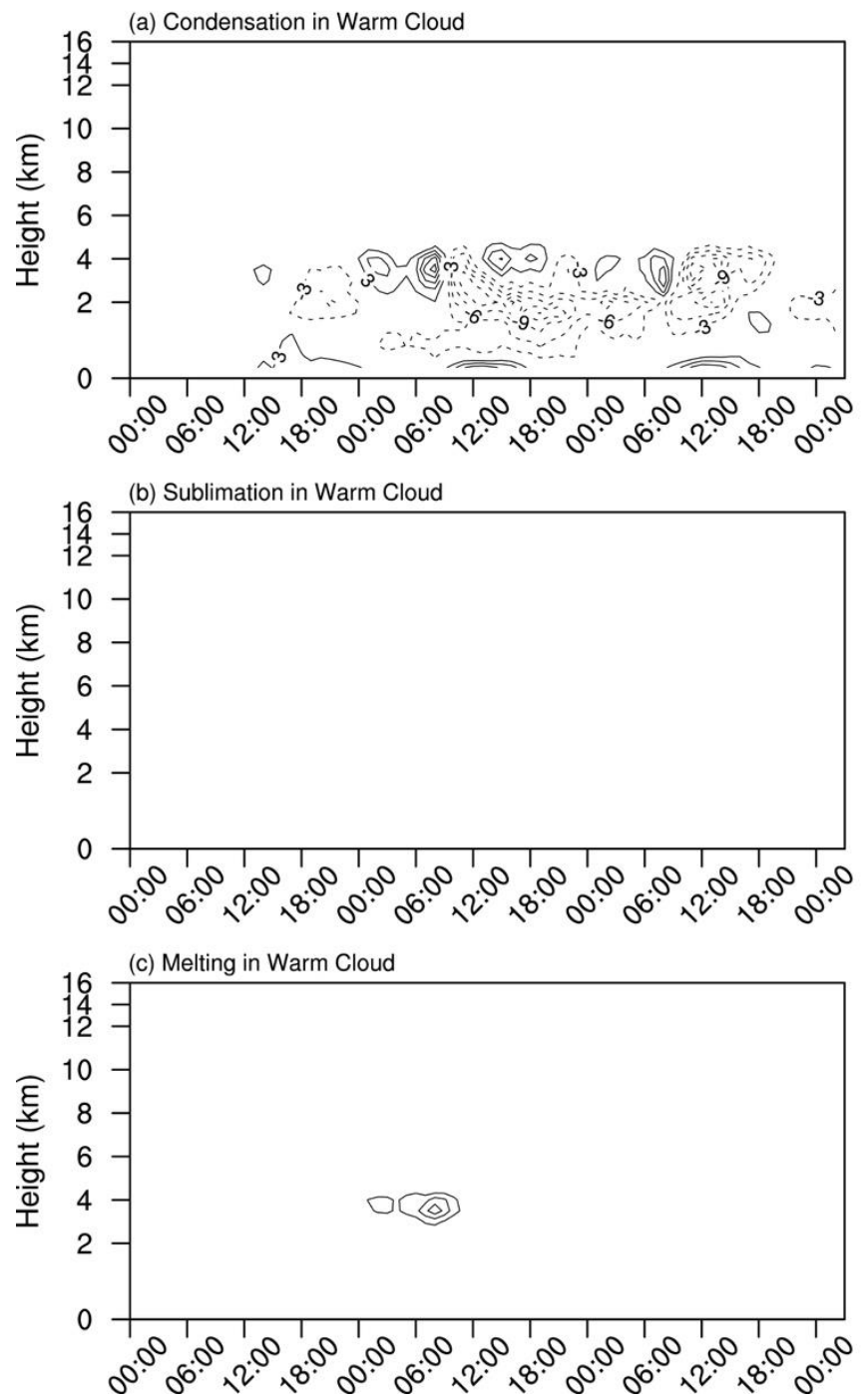

Cold Cloud
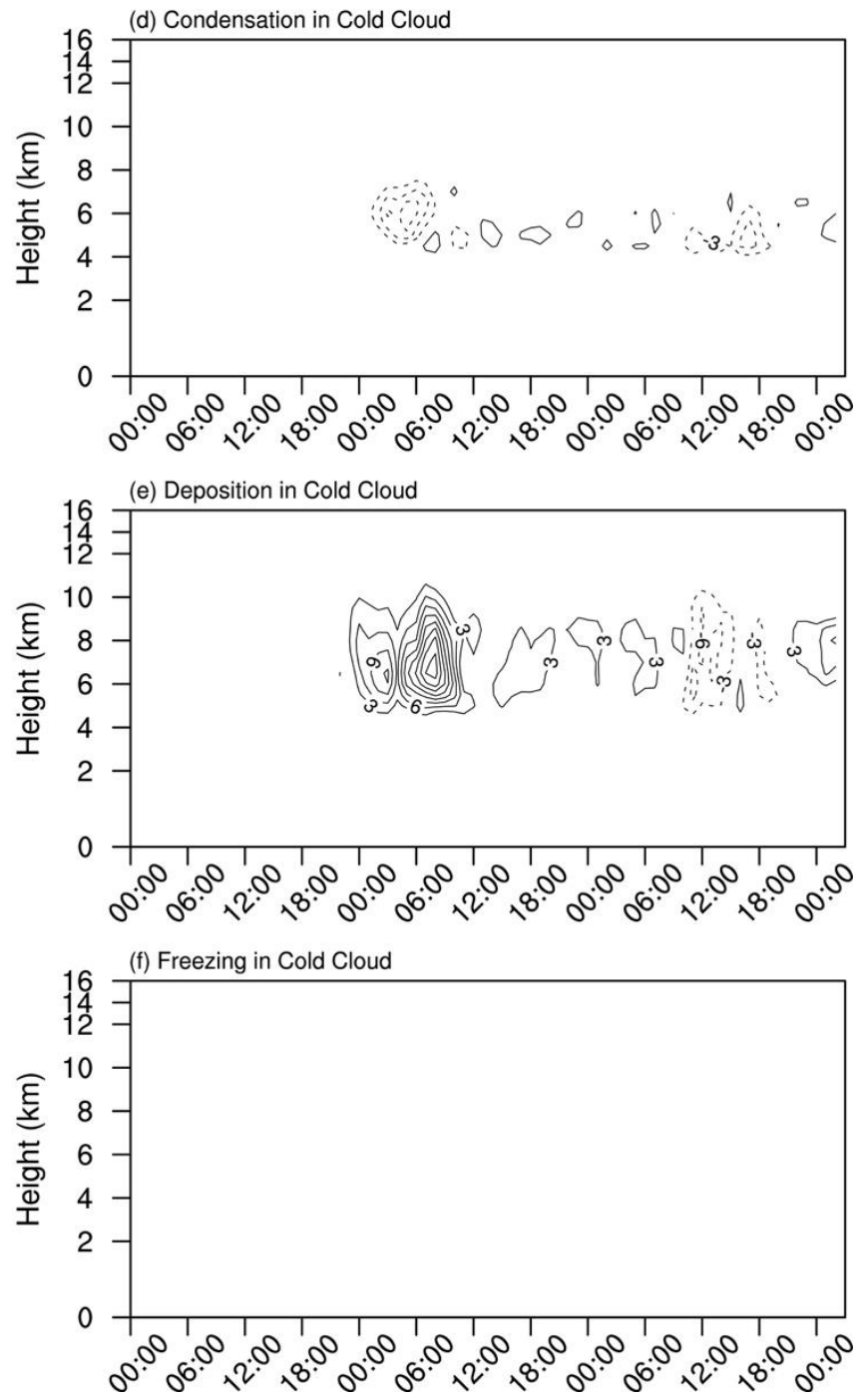

Figure S19. Differences with time (abscissa) and height (ordinate) in latent heat release $\left(\mathrm{K} \mathrm{d}^{-1}\right)$ from (a) condensation, (b) deposition, and (c) freezing processes between 10x and CLEAN averaged over R1 for warm cloud. (d-f) Same as (a-c) but for cold cloud. 


\section{Wind Shear}

(a) $2013-12-14$

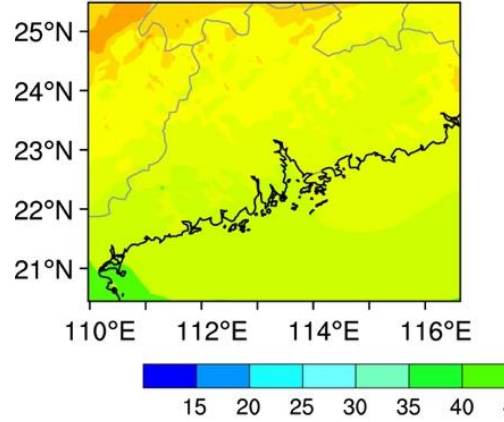

(b) 2013-12-15

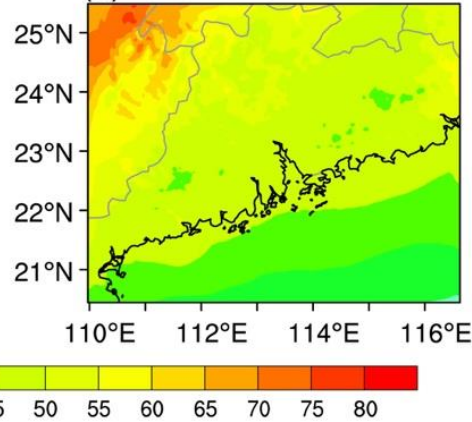

Water Vapor \& 925-hPa Wind

(c) 2013-12-14

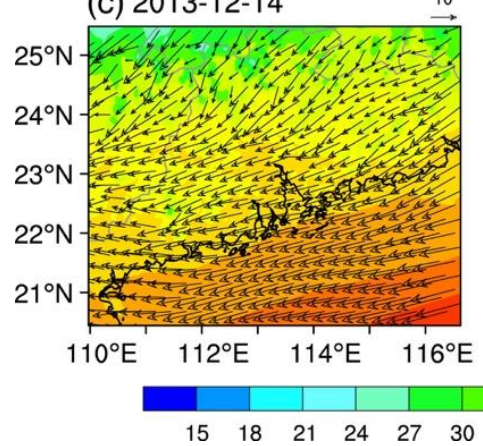

(d) 2013-12-15

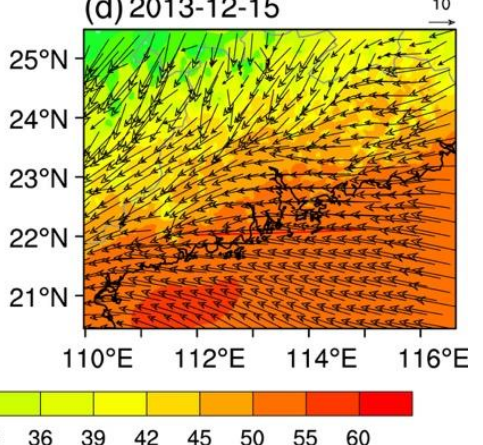

Figure S20. Spatial distribution of wind shear $\left(\mathrm{m} \mathrm{s}^{-1}\right)$ on (a) December 14 and (b) December 15 in 2013 in the CTL run. Wind shear is calculated as differences between maximum wind speed and minimum wind speed at 0-10 km. Spatial distribution of columnintegrated water vapor (shading; $\mathrm{mm} \mathrm{day}^{-1}$ ) and 925-hPa wind (vector; $\mathrm{m} \mathrm{s}^{-1}$ ) on (c) December 14 and (d) December 15 in 2013 in CTL. 

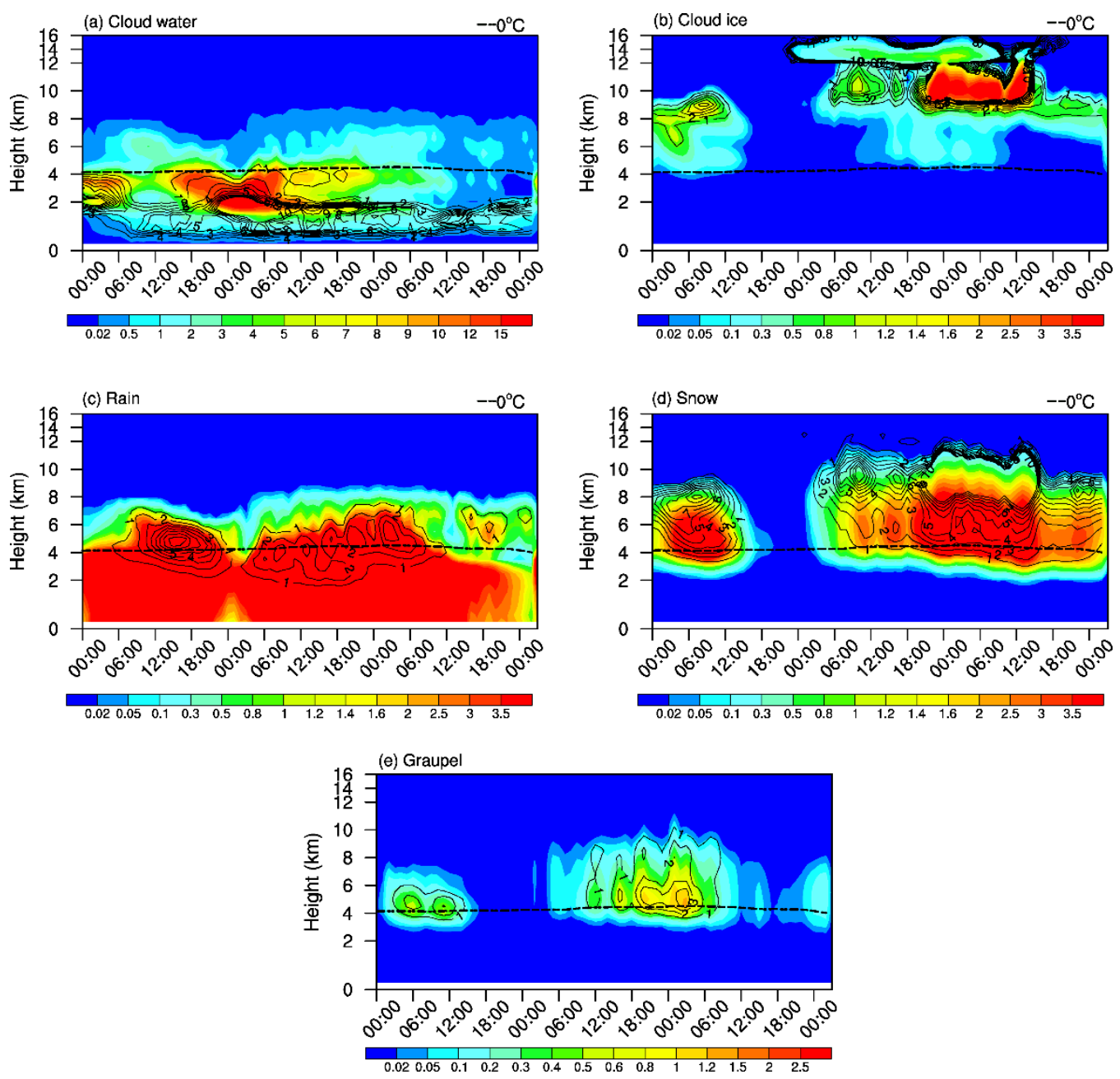

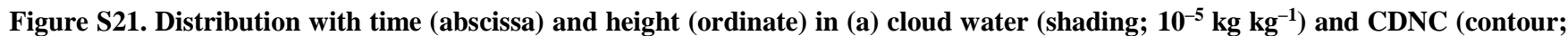
unit: $10^{7} \mathrm{~kg}^{-1}$ ), (b) cloud ice (shading; $10^{-5} \mathrm{~kg} \mathrm{~kg}^{-1}$ ) and CINC (contour; $10^{4} \mathrm{~kg}^{-1}$ ), (c) rain (shading; $10^{-5} \mathrm{~kg} \mathrm{~kg}^{-1}$ ) and rain number concentration (contour; $10^{5} \mathrm{~kg}^{-1}$ ), (d) snow (shading; $10^{-4} \mathrm{~kg} \mathrm{~kg}^{-1}$ ) and snow number concentrations (contour; $\left.10^{3} \mathrm{~kg}^{-1}\right)$, and $(\mathrm{e})$ graupel (shading; $10^{-4} \mathrm{~kg} \mathrm{~kg}^{-1}$ ) and graupel number concentration (contour; $10^{3} \mathrm{~kg}^{-1}$ ) averaged over R2 from CTL run. 

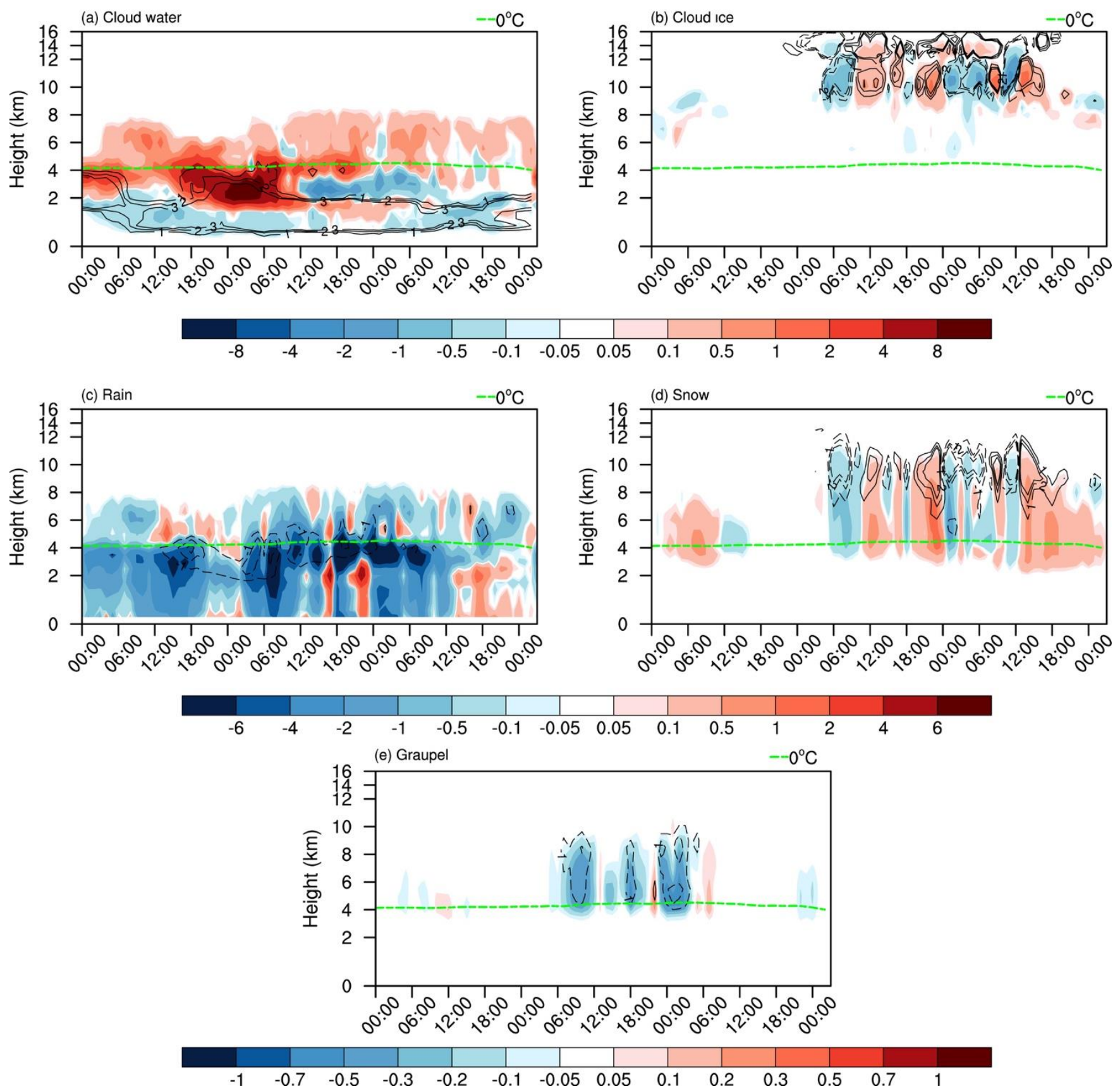

Figure S22. Differences with time (abscissa) and height (ordinate) in (a) cloud water (shading; $10^{-5} \mathbf{k g ~ k g}^{-1}$ ) and CDNC (contour; $10^{7} \mathrm{~kg}^{-1}$ ), (b) cloud ice (shading; $10^{-5} \mathrm{~kg} \mathrm{~kg}^{-1}$ ) and CINC (contour; $10^{4} \mathrm{~kg}^{-1}$ ), (c) rain (shading; $10^{-5} \mathrm{~kg} \mathrm{~kg}^{-1}$ ) and rain number concentration (contour; $10^{5} \mathrm{~kg}^{-1}$ ), (d) snow (shading; $10^{-4} \mathrm{~kg} \mathrm{~kg}^{-1}$ ) and snow number concentrations (contour; $10^{3} \mathrm{~kg}^{-1}$ ), and (e) graupel (shading; $10^{-4} \mathrm{~kg} \mathrm{~kg}^{-1}$ ) and graupel number concentration (contour; $10^{3} \mathrm{~kg}^{-1}$ ) between CTL and CLEAN averaged over R2. 
Warm Cloud
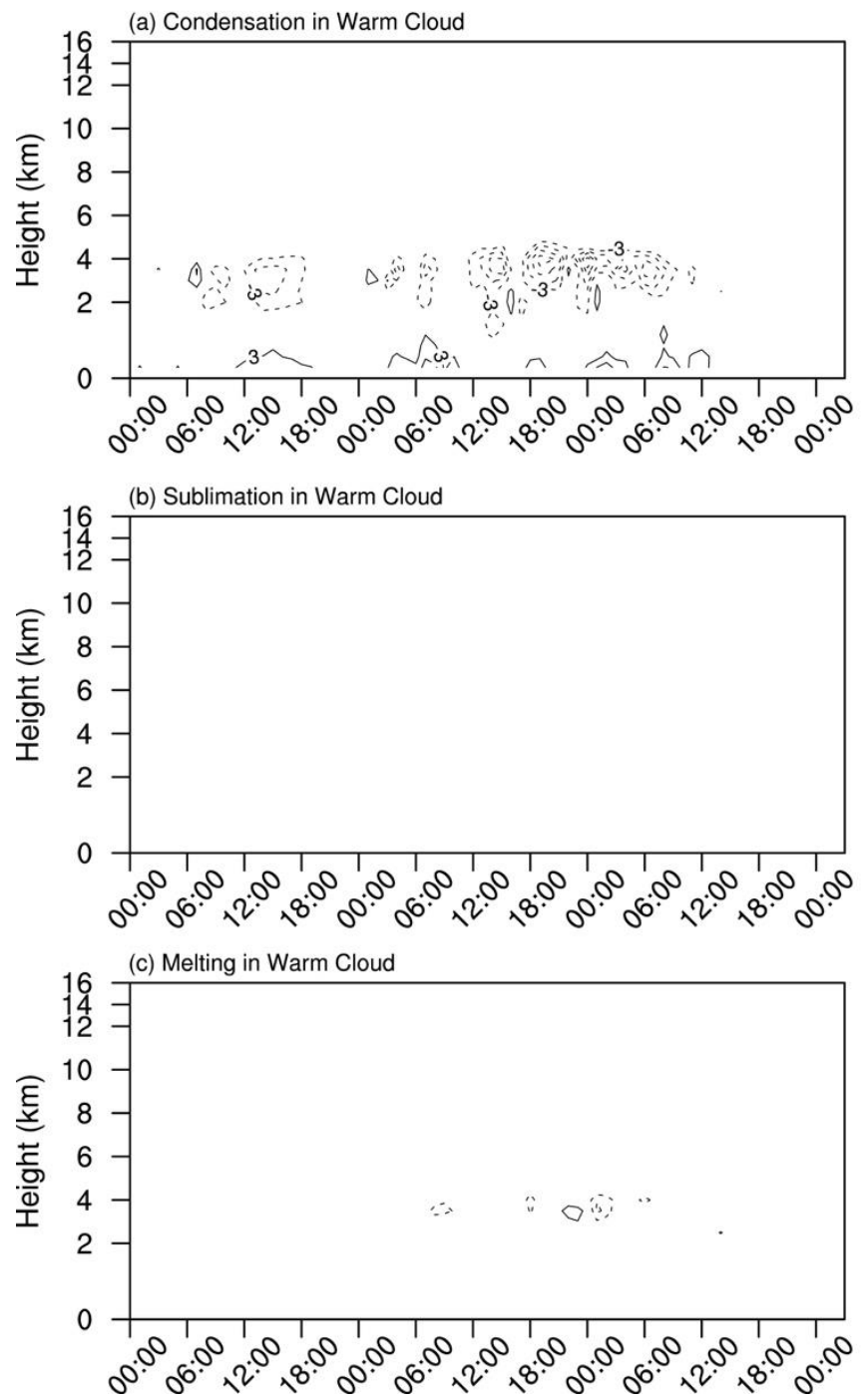

Cold Cloud
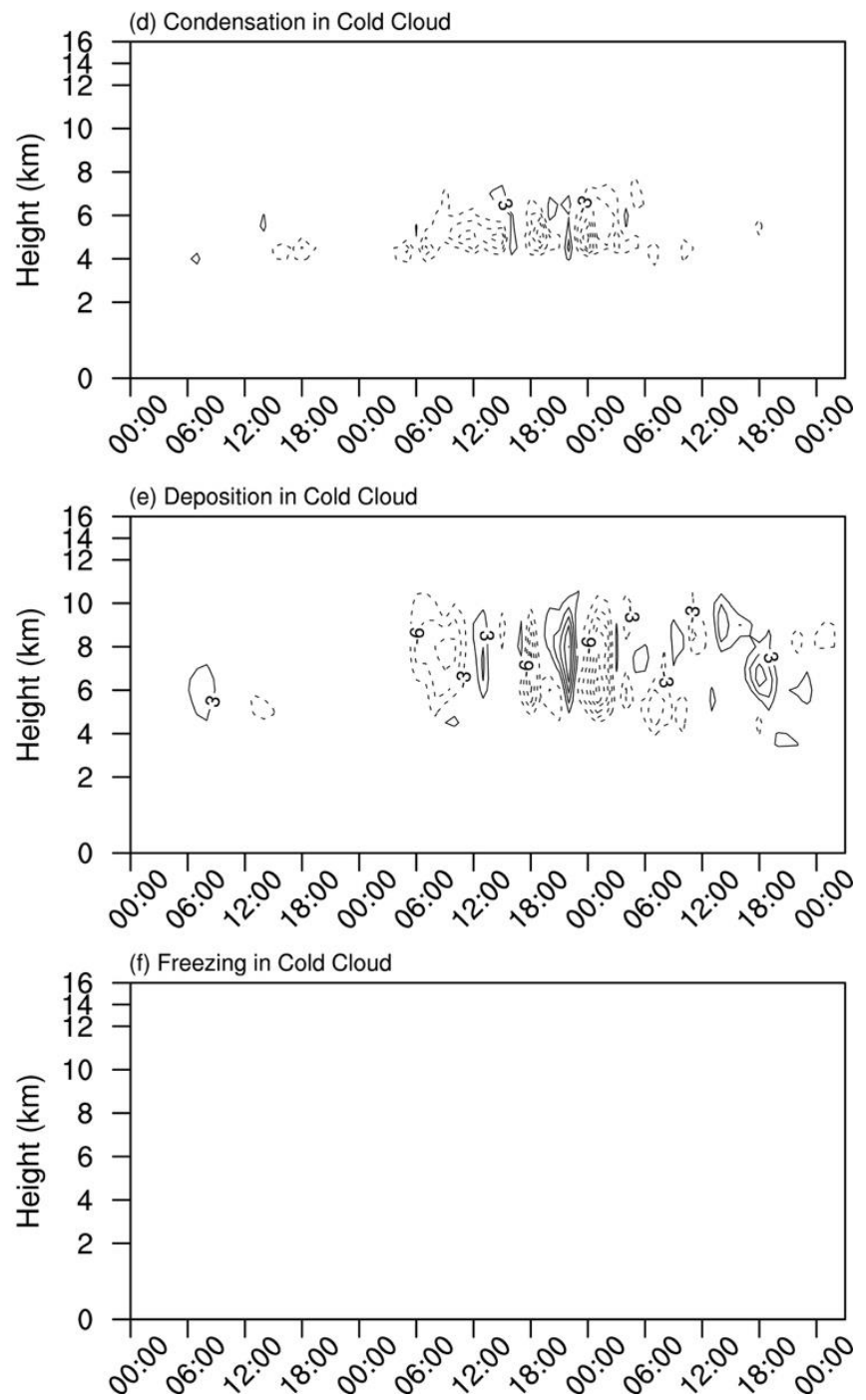

Figure S23. Differences with time (abscissa) and height (ordinate) in latent heat release ( $\left.\mathrm{K} \mathrm{d}^{-1}\right)$ from (a) condensation, (b) deposition, and (c) freezing processes between CTL and CLEAN averaged over R2 for warm cloud. (d-f) Same as (a-c) but for cold cloud. 

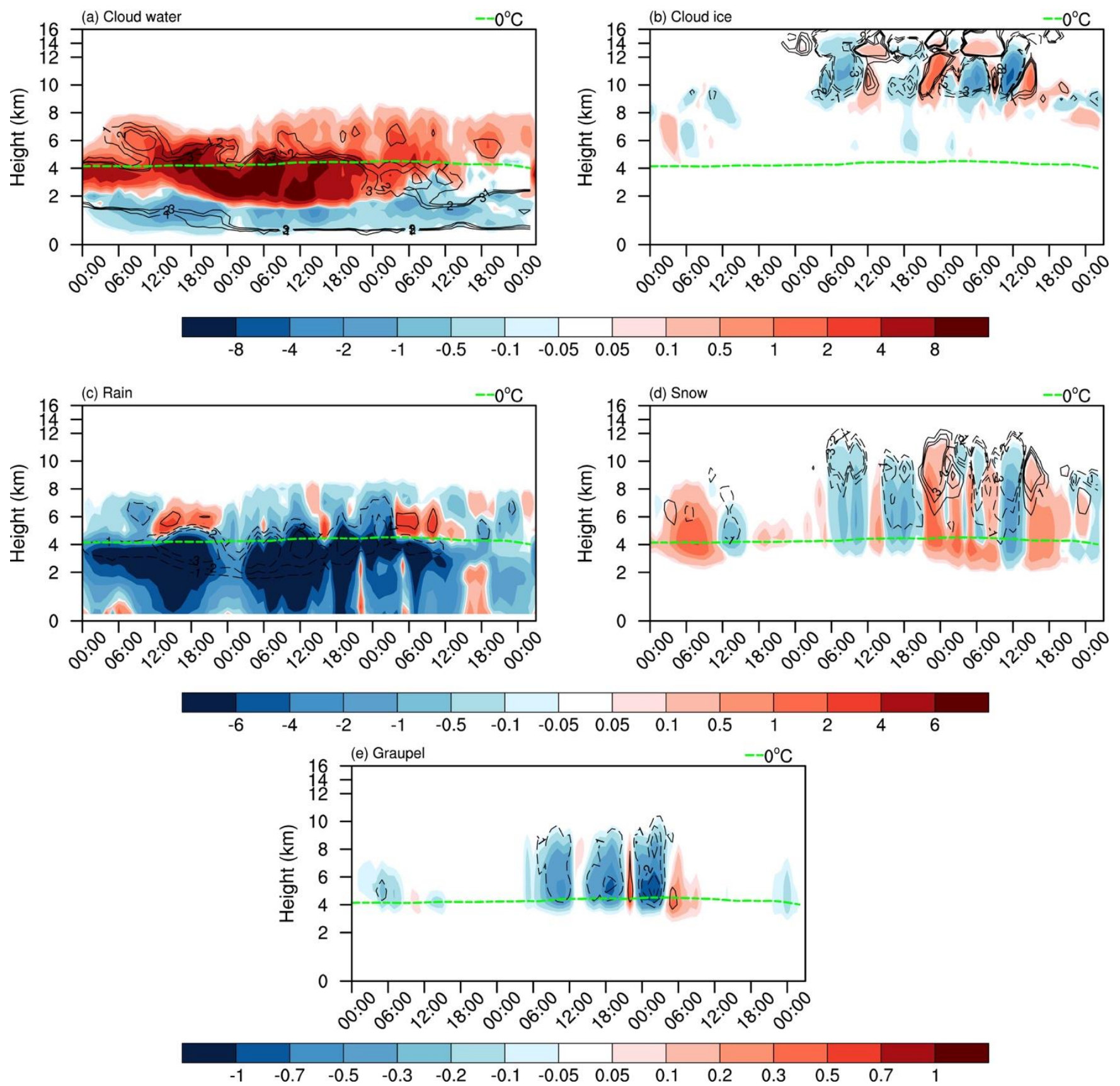

Figure S24. Differences with time (abscissa) and height (ordinate) in (a) cloud water (shading; $\mathbf{1 0}^{-5} \mathrm{~kg} \mathrm{~kg}^{-1}$ ) and CDNC (contour; $10^{7} \mathrm{~kg}^{-1}$ ), (b) cloud ice (shading; 10 ${ }^{-5} \mathrm{~kg} \mathrm{~kg}^{-1}$ ) and CINC (contour; $10^{4} \mathrm{~kg}^{-1}$ ), (c) rain (shading; 10-5 $\mathrm{kg} \mathrm{kg}^{-1}$ ) and rain number concentration (contour; $10^{5} \mathrm{~kg}^{-1}$ ), (d) snow (shading; $10^{-4} \mathrm{~kg} \mathrm{~kg}^{-1}$ ) and snow number concentrations (contour; $10^{3} \mathrm{~kg}^{-1}$ ), and (e) graupel (shading; $10^{-4} \mathrm{~kg} \mathrm{~kg}^{-1}$ ) and graupel number concentration (contour; $10^{3} \mathrm{~kg}^{-1}$ ) between $10 \times$ and CLEAN averaged over R2. 
Warm Cloud
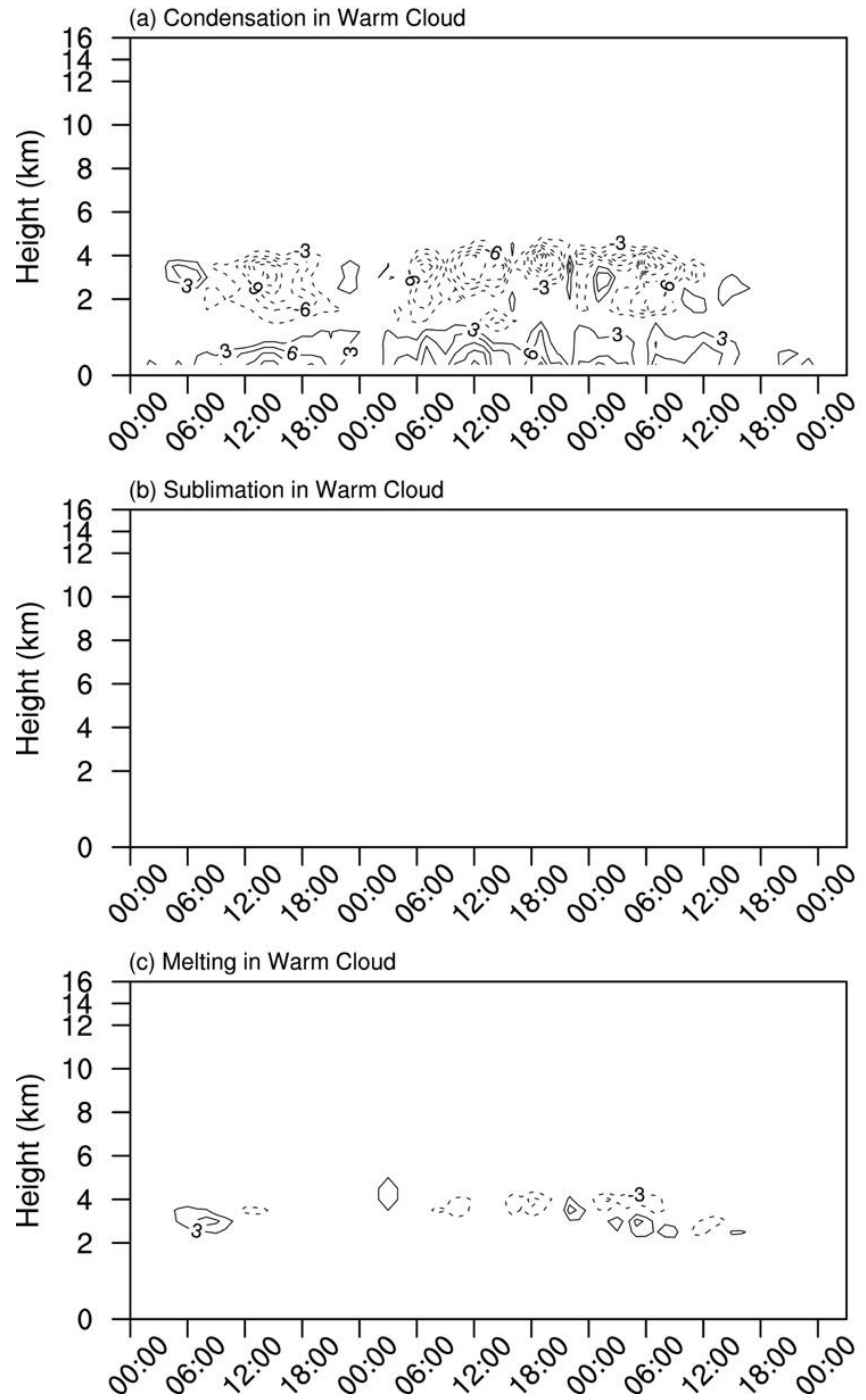

Cold Cloud
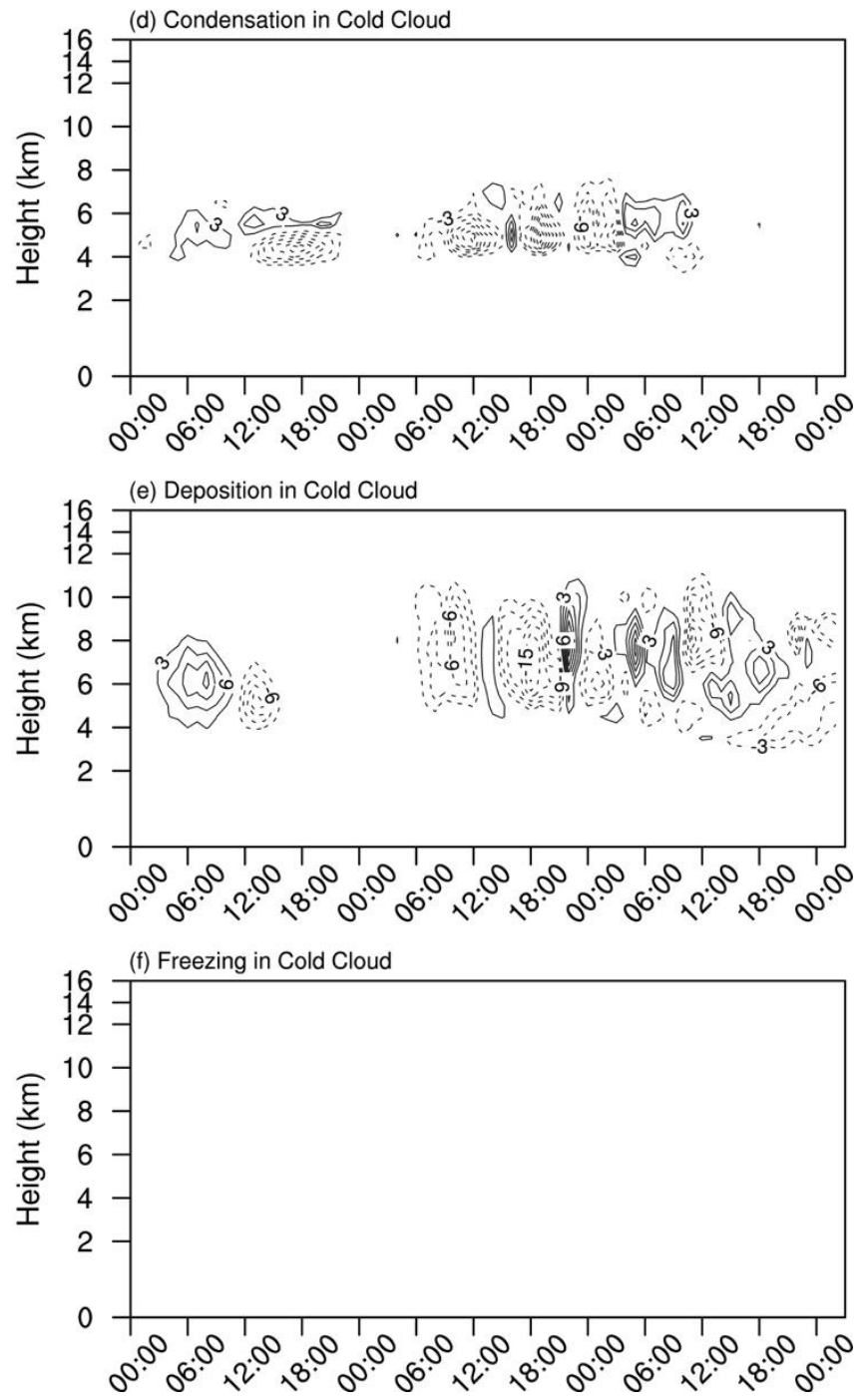

Figure S25. Differences with time (abscissa) and height (ordinate) in latent heat release $\left(\mathrm{K} \mathrm{d}^{-1}\right)$ from (a) condensation, (b) deposition, and (c) freezing processes between 10x and CLEAN averaged over $\mathbf{R} 2$ for warm cloud. (d-f) Same as (a-c) but for cold cloud. 
(a) CTL-CLEAN

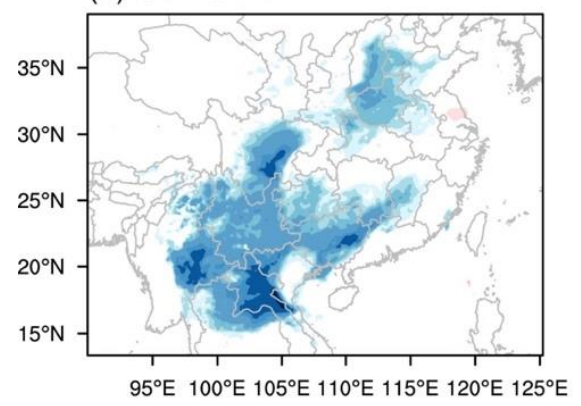

(b) D1-CLEAN

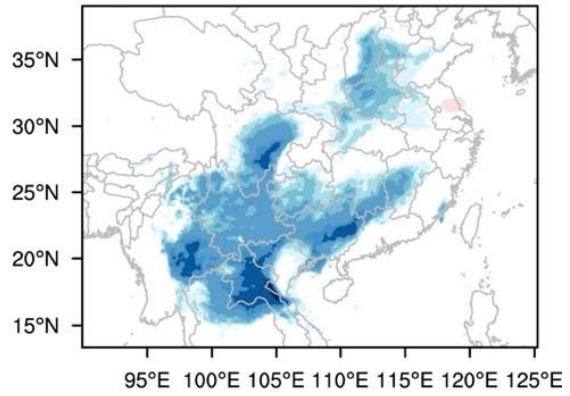

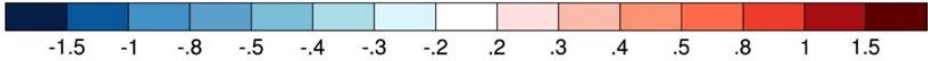

Column Water Vapor

(c) CTL-CLEAN

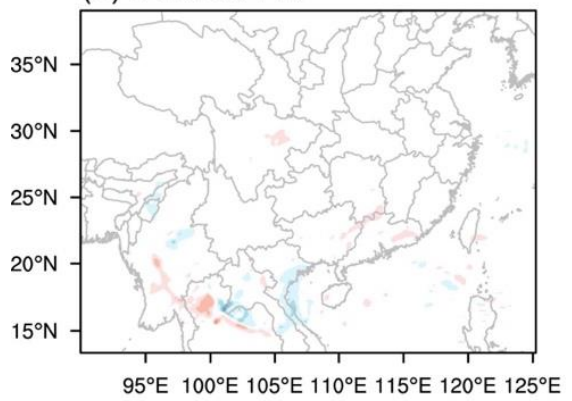

(d) D1-CLEAN

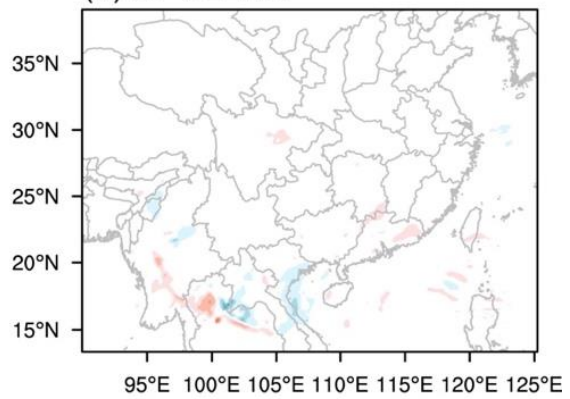

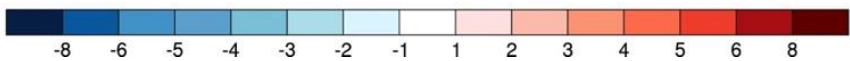

Figure S26. Differences in 2-m temperature (K) between (a) CTL and CLEAN and (b) D1 and CLEAN on December 15. (c, d) Same as (a, b) but for column water vapor $(\mathbf{m m})$.

\section{Precipitation}

\section{(a) CTL-CLEAN}

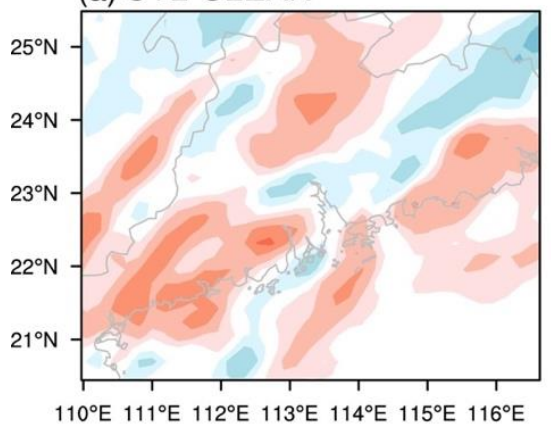

(b) D1-CLEAN

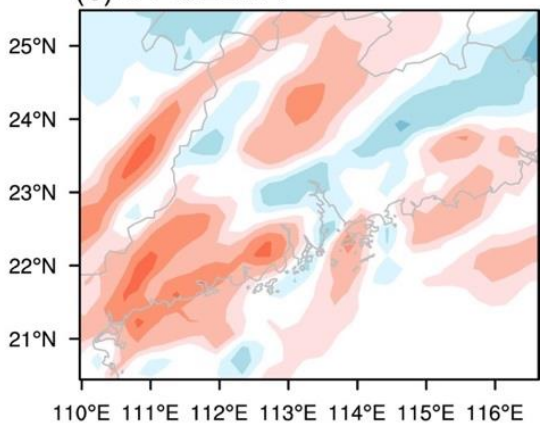

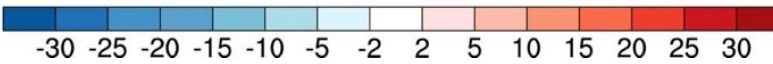

Figure S27. Differences in precipitation (mm) between (a) CTL and CLEAN and (b) D1 and CLEAN on December 15 based on domain 1 output. 


\section{References}

Binkowski, F. S. and Shankar, U.: The regional particulate matter model: 1. Model description and preliminary results, J. Geophys. Res., 100(D12), 26191, doi:10.1029/95JD02093, 1995.

Chapman, E. G., Gustafson, W. I., Easter, R. C., Barnard, J. C., Ghan, S. J., Pekour, M. S. and Fast, J. D.: Coupling aerosolcloud-radiative processes in the WRF-Chem model: Investigating the radiative impact of elevated point sources, Atmos. Chem. Phys., 9(3), 945-964, doi:10.5194/acp-9-945-2009, 2009.

Chen, F. and Dudhia, J.: Coupling an advanced land surface-hydrology model with the Penn State-NCAR MM5 modeling system. Part I: Model implementation and sensitivity, Mon. Weather Rev., 129(4), 569-585, doi:10.1175/15200493(2001)129<0569:CAALSH>2.0.CO;2, 2001.

Easter, R. C., Ghan, S. J., Zhang, Y., Saylor, R. D., Chapman, E. G., Laulainen, N. S., Abdul-Razzak, H., Leung, L. R., Bian, X. and Zaveri, R. A.: MIRAGE: Model description and evaluation of aerosols and trace gases, J. Geophys. Res. D Atmos., 109(20), doi:10.1029/2004JD004571, 2004.

Fast, J. D., Gustafson, W. I., Easter, R. C., Zaveri, R. A., Barnard, J. C., Chapman, E. G., Grell, G. A. and Peckham, S. E.: Evolution of ozone, particulates, and aerosol direct radiative forcing in the vicinity of Houston using a fully coupled meteorology-chemistry-aerosol model, J. Geophys. Res. Atmos., 111(21), 1-29, doi:10.1029/2005JD006721, 2006.

Hong, S.-Y., Noh, Y. and Dudhia, J.: A new vertical diffusion package with an explicit treatment of entrainment processes., Mon. Weather Rev., 134(9), 2318-2341, doi:10.1175/MWR3199.1, 2006.

Iacono, M. J., Delamere, J. S., Mlawer, E. J., Shephard, M. W., Clough, S. A. and Collins, W. D.: Radiative forcing by longlived greenhouse gases: Calculations with the AER radiative transfer models, , 113, 2-9, doi:10.1029/2008JD009944, 2008.

Kain, J. S. and J. M. Fritsch: A one-dimensional entraining/detraining plume model and its application in convective parameterization, J. Atmos. Sci., 47, 2784-2802, doi.org/10.1175/1520-0469(1990)047<2784:AODEPM>2.0.CO;2, 1990.

Morrison, H., Thompson, G. and Tatarskii, V.: Impact of cloud microphysics on the development of trailing stratiform precipitation in a simulated squall line: Comparison of one- and two-moment schemes, Mon. Weather Rev., 137(3), 9911007, doi:10.1175/2008MWR2556.1, 2009.

Skamarock, W. C., Klemp, J. B., Dudhia, J., Gill, D. O., Barker, D. M., Duda, M. G., Huang, X.-Y., Wang, W. and Powers, J. G.: A description of the advanced research WRF version 3. [online] Available from: https://pdfs.semanticscholar.org/ace5/4d4d1d6c9914997ad8f4e410044fdeb95b9d.pdf (Accessed 15 May 2018), 2008.

Yang, Q., Gustafson, W. I., Fast, J. D., Wang, H., Easter, R. C., Morrison, H., Lee, Y. N., Chapman, E. G., Spak, S. N. and Mena-Carrasco, M. A.: Assessing regional scale predictions of aerosols, marine stratocumulus, and their interactions during VOCALS-REx using WRF-Chem, Atmos. Chem. Phys., 11(23), 11951-11975, doi:10.5194/acp-11-11951-2011, 2011.

Zaveri, R. A. and Peters, L. K.: A new lumped structure photochemical mechanism for large-scale applications, J. Geophys. 
Res. Atmos., 104(D23), 30387-30415, doi:10.1029/1999JD900876, 1999.

Zaveri, R. A., Easter, R. C., Fast, J. D. and Peters, L. K.: Model for simulating aerosol interactions and chemistry (MOSAIC), J. Geophys. Res. Atmos., 113(13), doi:10.1029/2007JD008782, 2008.

Zhao, C., Wang, Y., Choi, Y. and Zeng, T.: Summertime impact of convective transport and lightning NOx production over North America: Modeling dependence on meteorological simulations, Atmos. Chem. Phys., 9(13), 4315-4327, doi:10.5194/acp-9-4315-2009, 2009.

Zhao, C., Liu, X., Leung, L. R., Johnson, B., Mcfarlane, S. A., Jr, W. I. G., Fast, J. D. and Easter, R.: The spatial distribution of mineral dust and its shortwave radiative forcing over North Africa: modeling sensitivities to dust emissions and aerosol size treatments, Atmos. Chem. Phys., 10, 8821-8838, doi:10.5194/acp-10-8821-2010, 2010.

Zhao, C., Liu, X., Leung, L. R. and Hagos, S.: and Physics Radiative impact of mineral dust on monsoon precipitation variability over West Africa, (2007), 1879-1893, doi:10.5194/acp-11-1879-2011, 2011.

Zhao, C., Chen, S., Leung, L. R., Qian, Y., Kok, J. F., Zaveri, R. A. and Huang, J.: Uncertainty in modeling dust mass balance and radiative forcing from size parameterization, Atmos. Chem. Phys., 13(21), 10733-10753, doi:10.5194/acp-13-107332013, 2013. 